\title{
A ocupação e o uso do solo no litoral paranaense: condicionantes, conflitos e tendências
}

\section{The occupation and land use in the coast of Paraná: conditionals, conflicts and tendencies}

\author{
Naína PIERRI* \\ Rodolfo José ANGULO** \\ Maria Cristina de SOUZA*** \\ Milena K. KIM****
}

\begin{abstract}
RESUMO
O objetivo deste artigo é apresentar as formas de ocupação e uso do litoral paranaense com foco na especificidade costeira, trazendo os elementos descritivos fundamentais, mas tentando pesquisar alguns fatores condicionantes e explicativos, assim como perceber as tendências presentes. As formas atuais principais do uso do solo costeiro no Paraná são o portuário, o pesqueiro, o turístico e a conservação de ecossistemas presentes e de sua biodiversidade. Para conhecer sua origem e compreender sua forma atual, apresenta-se o histórico da região e se aportam dados que caracterizam e dimensionam esses quatro usos do solo costeiro. A partir disso, analisam-se as condicionantes físicas desses usos, assim como suas consequiências em termos de conflitos e tendências. Por último, apresentam-se dados básicos da dinâmica populacional, entendida como reflexo ou expressão da dinâmica econômica que preside a ocupação do espaço e a apropriação e uso dos recursos. Desta forma, o artigo tenta captar a dialética entre as condições naturais e os processos históricos que determinam a configuração do espaço social.

Palavras-chave: ocupação e uso do solo; regiões costeiras; dinâmicas naturais e sociais.
\end{abstract}

\section{ABSTRACT}

The aim of the present article is to present the forms of occupation and use of the coastal area of Paraná, bringing the fundamental descriptive elements, but also trying to research some conditional and explicative factors, as well as noticing the present tendencies. The main current forms of coastal

\footnotetext{
* Doutora em Meio Ambiente e Desenvolvimento. Professora do Centro de Estudos do Mar e do Doutorado em Meio Ambiente e Desenvolvimento da Universidade Federal do Paraná.naina@cem.ufpr.br

** Doutor em Geologia. Professor do Departamento de Geologia e do Doutorado em Meio Ambiente e Desenvolvimento da Universidade Federal do Paraná. angulo@ ufpr.br

*** Doutora em Geologia. Professora do Departamento de Geologia de Universidade Federal do Paraná. cristinasouza@ufpr.br

**** Oceanógrafa. Mestranda em Gerenciamento Aquático e Costeiro, Universidade de Cádiz, Espanha. milenakkim@ yahoo.com.br
} 
land use in Paraná are related to harbors, fishing, tourism and the conservation of the present ecosystems and their biodiversity. In order to know its origin and comprehend its current form, it's presented the historic of the region and shown data which characterize and give dimension the four coastal land uses just mentioned above. From this information, the geomorphologic conditionals of these uses are analyzed, as well as their consequences, in terms of conflicts and tendencies. Finally, there is presented basic data of the populational dynamic, understood as a reflex or expression of the economic dynamic which controls the occupation of the space, and the appropriation and use of the resources. This way, this work tries to understand the dialectic between the natural conditions and the historical processes which determine the configuration of the social space.

Key-words: occupation and land use; coastal areas; social and natural dynamics.

\section{Introdução}

O objetivo deste artigo é apresentar as formas de ocupação e uso do litoral paranaense com foco na especificidade costeira, trazendo os elementos descritivos fundamentais, mas tentando pesquisar alguns fatores condicionantes e explicativos, assim como perceber as tendências presentes. A partir da identificação de que as formas principais do uso do solo costeiro atual são o portuário, o pesqueiro, o turístico e a conservação de ecossistemas presentes e de sua biodiversidade, apresenta-se o histórico da região, que permite compreender como se chega a esses usos atuais, aportam-se dados que possam caracterizar e/ou dimensionar ditos usos, exploram-se suas condicionantes biofísicas, e anotam-se os conflitos e tendências derivados. A escolha não é por fazer uma descrição exaustiva dos processos de ocupação e de todas as formas de uso do solo, nem por fazer um diagnóstico socioambiental da situação derivada deles. $\mathrm{O}$ foco está nos usos mais especificamente costeiros, tentando captar a dialética entre as condições naturais e históricas que determinam a configuração do espaço social.

Algumas interpretações teóricas orientam o tratamento do tema, de forma que, sem ter uma abordagem explícita, abona-se a discussão que já existe nessas questões, por meio da apresentação do caso. A primeira interpretação é a que discute a relação entre as determinantes naturais e as sociais para a ocupação do solo - os recursos naturais em geral - e a configuração econômica do seu uso. Nesse sentido, o artigo destaca a importância fundamental das condicionantes físicas para a ocupação humana, tanto em termos de oportunidades como de restrições. Mas traz ele- mentos que mostram que a determinação da ocupação e dos usos é fundamentalmente social, e que são os processos históricos concretos, conduzidos pelas forças sociais presentes, portadoras de certos níveis de riqueza e de tecnologia, que aproveitam ou não as oportunidades do ambiente físico, e respeitam ou não suas características e dinâmica.

A outra interpretação teórica que orienta a abordagem do trabalho é que a dinâmica demográfica está determinada, fundamentalmente, pela dinâmica econômica, e não o contrário. Assim, os elementos de dinâmica populacional que se apresentam mostram, com bastante eloqüência, ser um reflexo ou expressão dos processos de ocupação e uso orientados, principalmente, nem que não exclusivamente, pela economia.

\section{Localização e características físicas do litoral paranaense}

O litoral paranaense se localiza entre os paralelos $25^{\circ}$ e $26^{\circ}$ de latitude sul e $48^{\circ}$ e $49^{\circ}$ de longitude oeste. Tem uma superfície total de $6.061,2 \mathrm{~km}^{2}$, que representa apenas $3 \%$ da superfície do Paraná, e uma população total de 225.840 habitantes em 2000 (IBGE, 2001). Em 2006, teria atingido 280.833 habitantes, e em 2010 atingiria 311.216 habitantes, segundo estimativas do IBGE, acrescentando seu peso na população total do estado de $2,5 \%$ em 2000, a $2,7 \%$, e $2,9 \%$, respectivamente (IBGE, ${ }^{1} 2006$, apud DESCHAMPS, 2007).

Este litoral caracteriza-se pela sua diversidade física e biológica, que influenciou a ocupação, condicionando seus 
usos. Deste modo, a análise das inter-relações entre a base natural, a ocupação e seus usos pode contribuir para identificar e caracterizar conflitos e tendências.

O Paraná é um estado de planaltos, que perfazem em torno de $95 \%$ do território, sendo as outras duas unidades de paisagem a Serra do Mar e o litoral, com apenas 5\% (Figura 1). Contudo, a diversidade se concentra nessas duas unidades. Nelas ocorrem morros e serras de até $1.600 \mathrm{~m}$ de altitude, remanescentes de antigos planaltos, planícies e leques aluviais, planícies costeiras, grandes ilhas costeiras e amplos complexos estuarinos (Figura 2).

Os complexos estuarinos originam uma costa muito recortada. Enquanto a costa oceânica tem em torno de 100 $\mathrm{km}$, as costas estuarinas têm aproximadamente $1.300 \mathrm{~km}$. A extensa linha de costa, associada à diversidade geológica, geomorfológica e dinâmica do litoral, propicia a forma- ção de numerosos tipos de costa. Considerando a morfologia e a dinâmica de ondas, marés e correntes associadas, podem ser reconhecidos três tipos principais de costa: estuarinas, oceânica e de desembocadura (ANGULO, 1993) (Figura 3). As costas oceânicas são dominadas pela ação das ondas e se caracterizam por suas praias arenosas e dunas frontais (Figura 4). As costas estuarinas são dominadas pelas marés e apresentam planícies de maré com predomínio de manguezais (Figura 5). Já as costas de desembocadura são dominadas pela ação das ondas e das correntes de maré e se caracterizam por suas praias e por sua grande mobilidade (Figura 6). Neste tipo de costa são freqüentes intensos processos de erosão e sedimentação com grandes deslocamentos da linha de costa. Por exemplo, Angulo (1993) reportou recuo da linha de costa de $600 \mathrm{~m}$ em apenas três anos num setor da costa da Ilha das Peças (Figura 7).

\section{FIGURA 1 - REGIÕES GEOGRÁFICAS NATURAIS DO ESTADO DO PARANÁ, SEGUNDO MAACK (1968)}

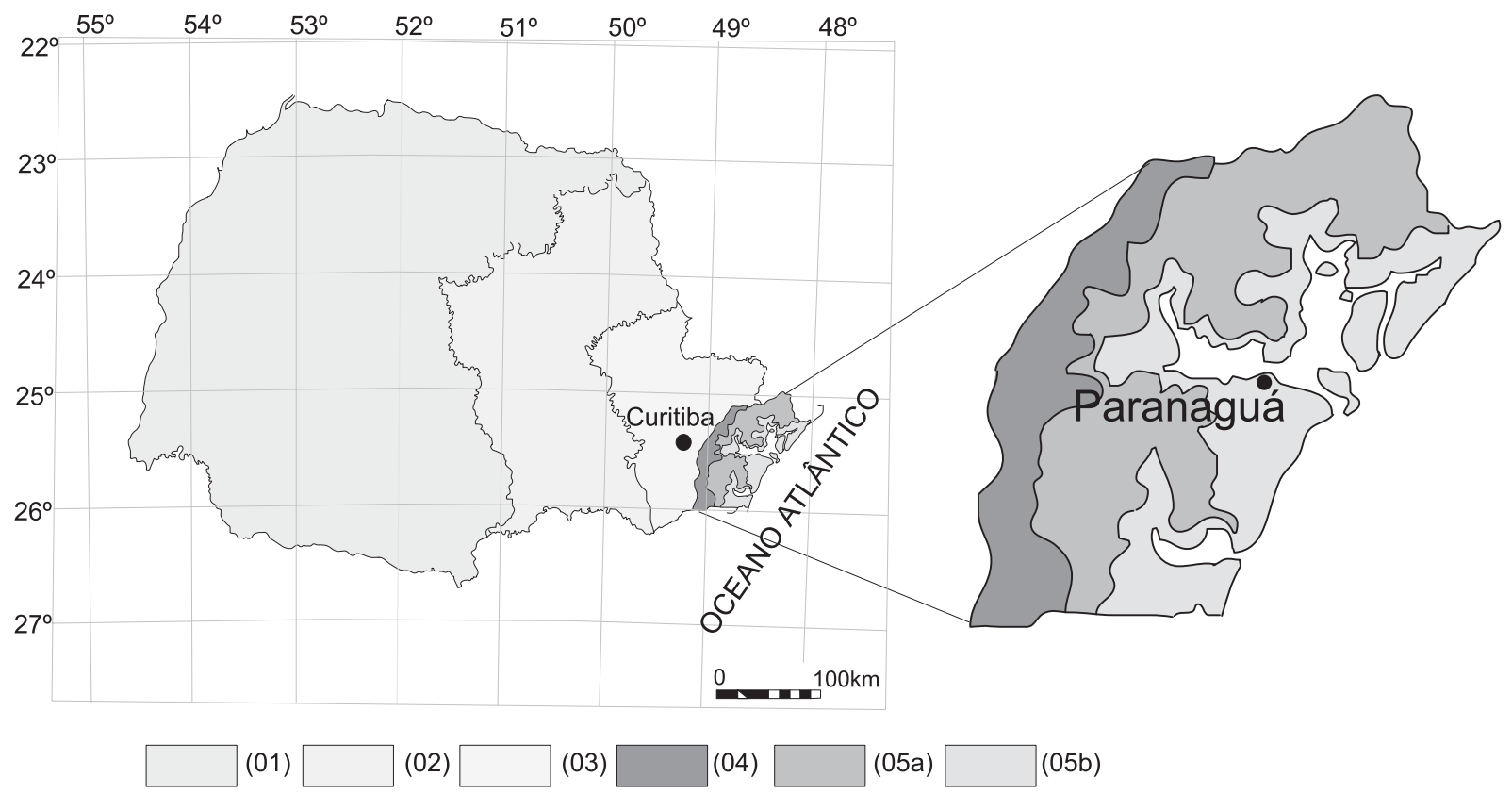

(1) TERCEIRO PLANALTO; (2) SEGUNDO PLANALTO; (3) PRIMEIRO PLANALTO; (4) SERRA DO MAR; (5) ZONA LITORAL QUE É COMPOSTA PELA (5A) ORLA MARINHA E (5B) ORLA DA SERRA. 
FIGURA 2 - PRINCIPAIS UNIDADES GEOMORFOLÓGICAS DA REGIÃO LITORÂNEA PARANAENSE (MODIFICADO DE ANGULO, 2004)
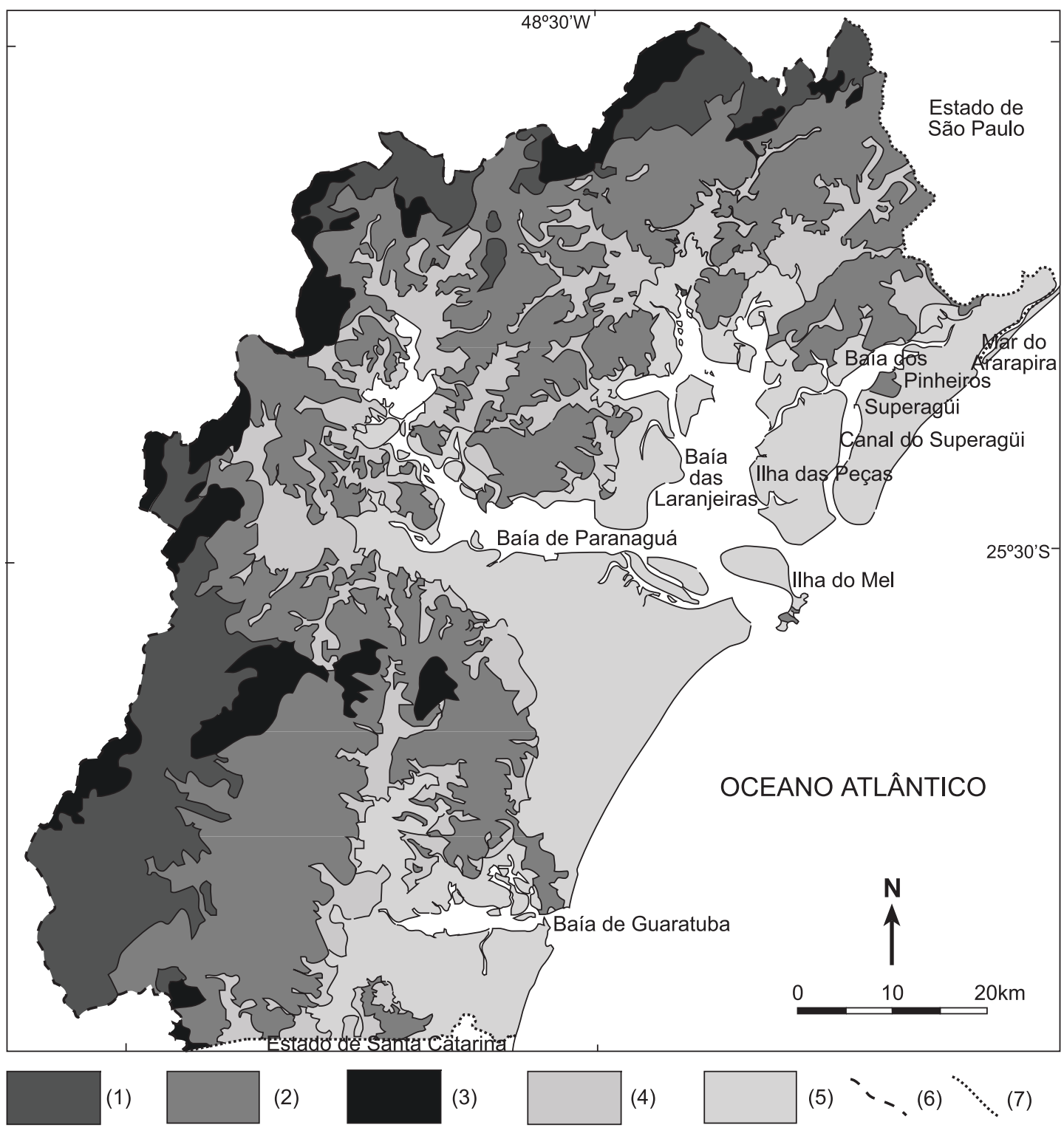

(1)

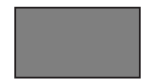

(2)

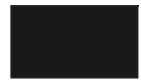

(3)

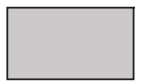

(4)

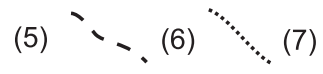

(1) PLANALTOS; (2) SERRAS ORIGINADAS POR DISSECAÇÃO DE BORDA DE PLANALTO; (3) SERRAS ORIGINADAS POR EROSÃO DIFERENCIAL; (4) TÁLUS, LEQUES ALUVIAIS E PLANÍCIES ALUVIAIS; (5) PLANÍCIE COSTEIRA; (6) DIVISOR DE ÁGUAS; (7) LIMITE INTERESTADUAL. 
FIGURA 3 - PRINCIPAIS TIPOS DA COSTA (MODIFICADO DE ANGULO; ARAÚJO, 1996) E DISTRIBUIÇÃO DOS SISTEMAS DE PESCA NO LITORAL PARANAENSE (MODIFICADO DE ANDRIGUETTO FILHO ET AL, 2005). COSTA OCEÂNICA (AZUL), ESTUARINA(VERDE) E DE DESEMBOCADURA(VERMELHO)

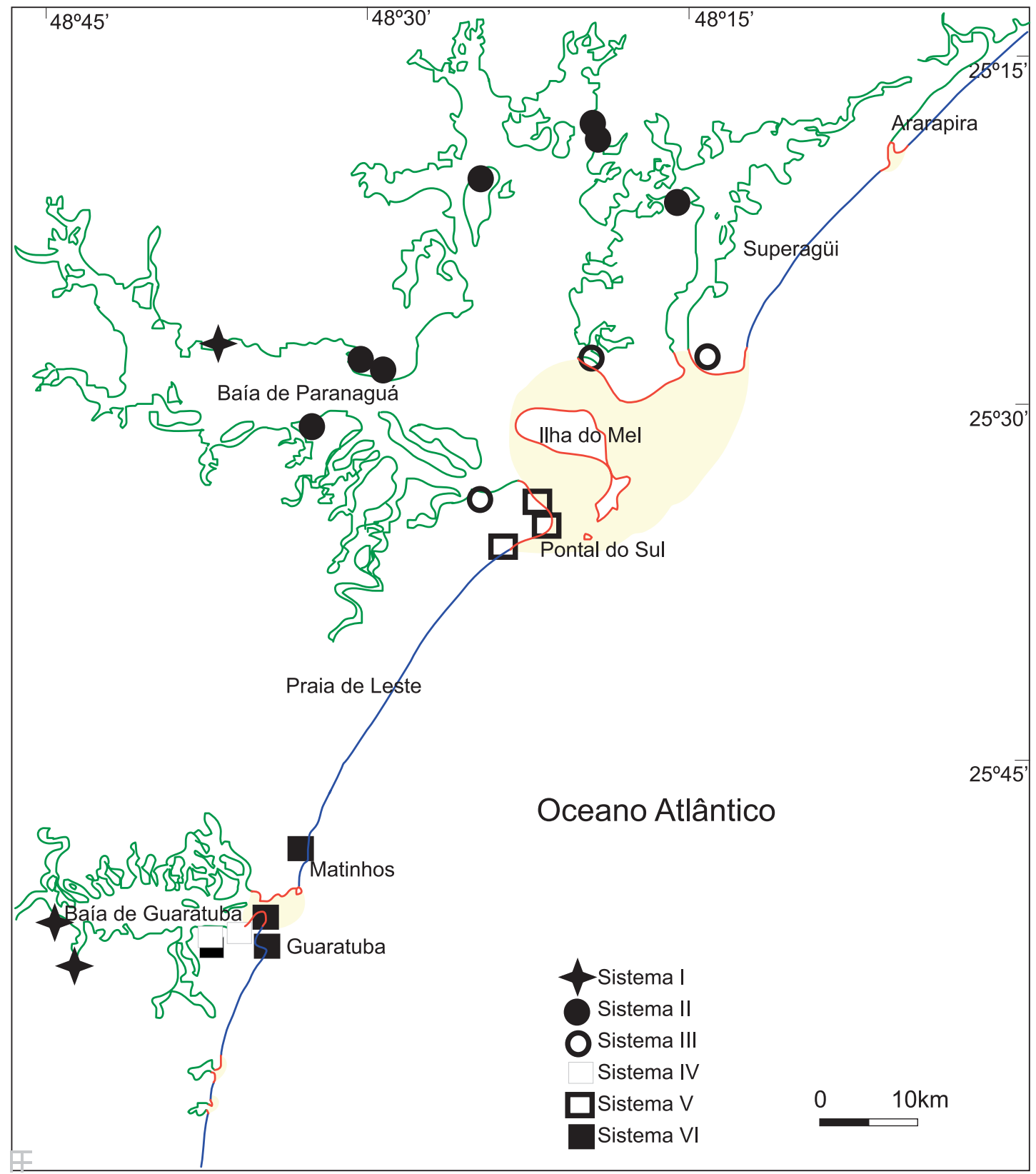


FIGURA 4 - COSTA OCEÂNICA COM PRAIAE DUNAS FRONTAIS, PRAIA DESERTA, SUPERAGÜI

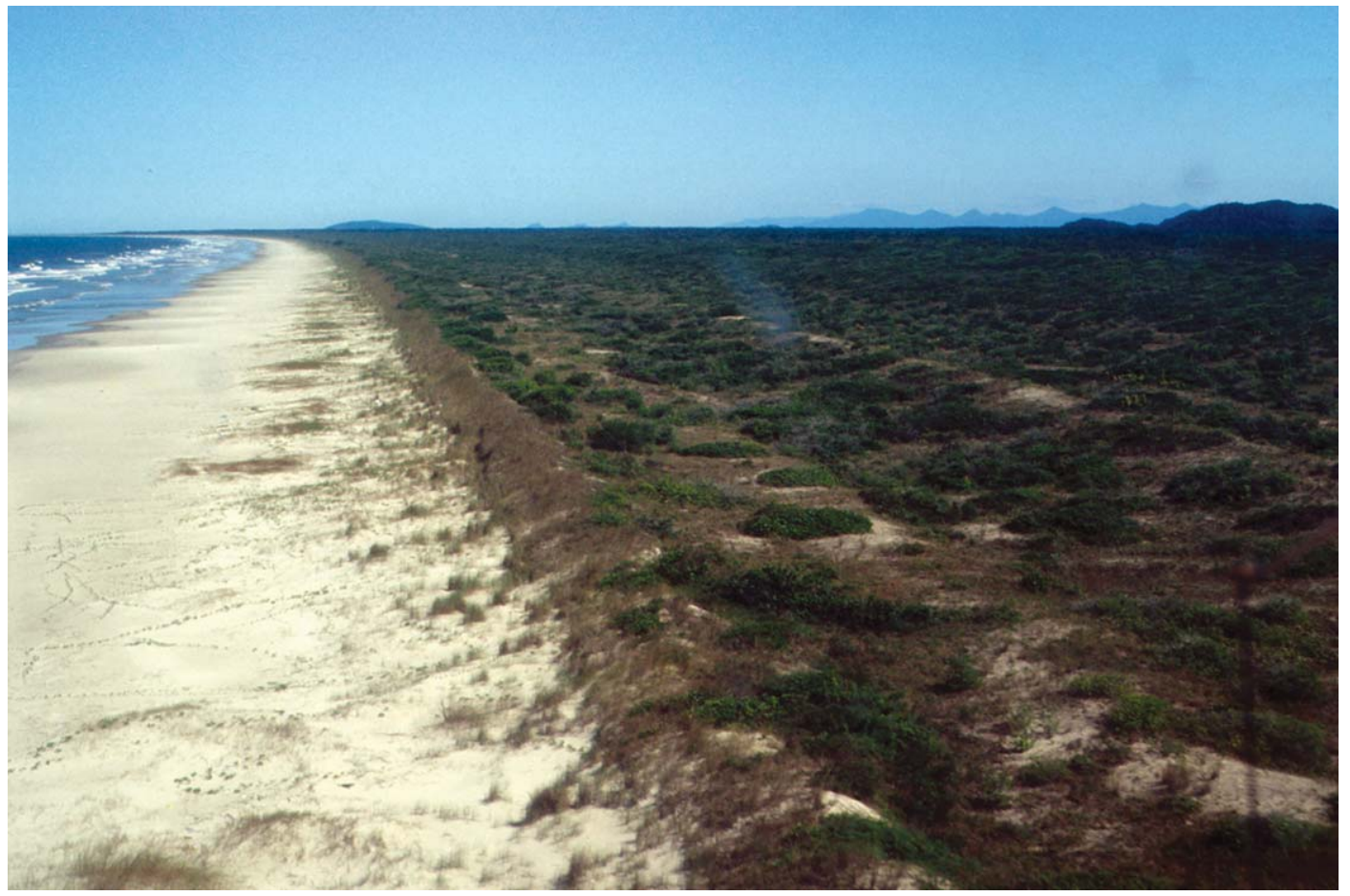

FIGURA 5 - COSTAESTUARINA COM MANGUEZAIS, BAÍA DOS PINHEIROS

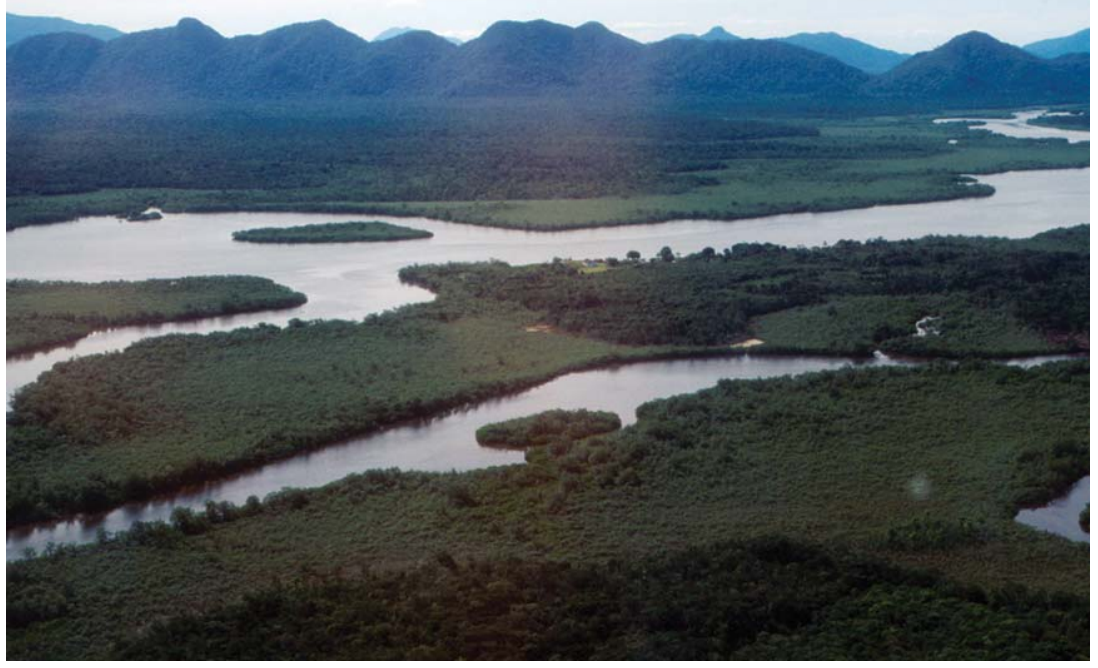


FIGURA 6 - COSTA DE DESEMBOCADURA, BARRA DO SUPERAGÜI

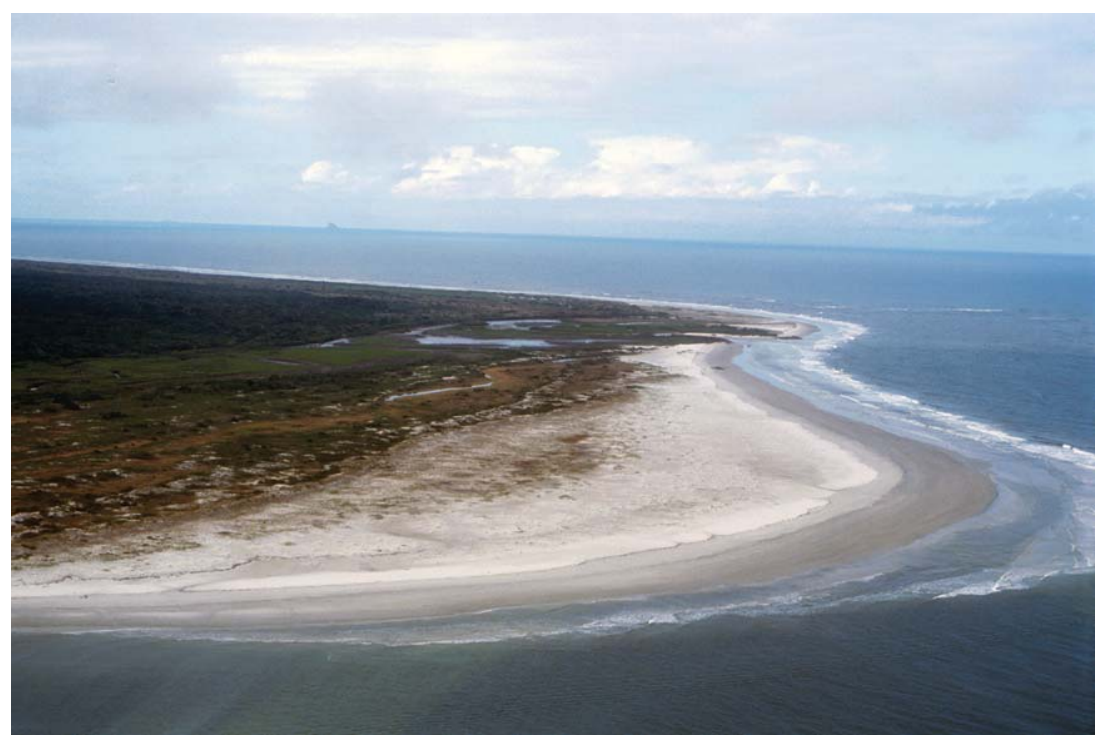

FIGURA 7 - VARIAÇÃO DA COSTA NA PONTA DO SUL DA ILHA DAS PEÇAS (MODIFICADO DE ANGULO, 1993)

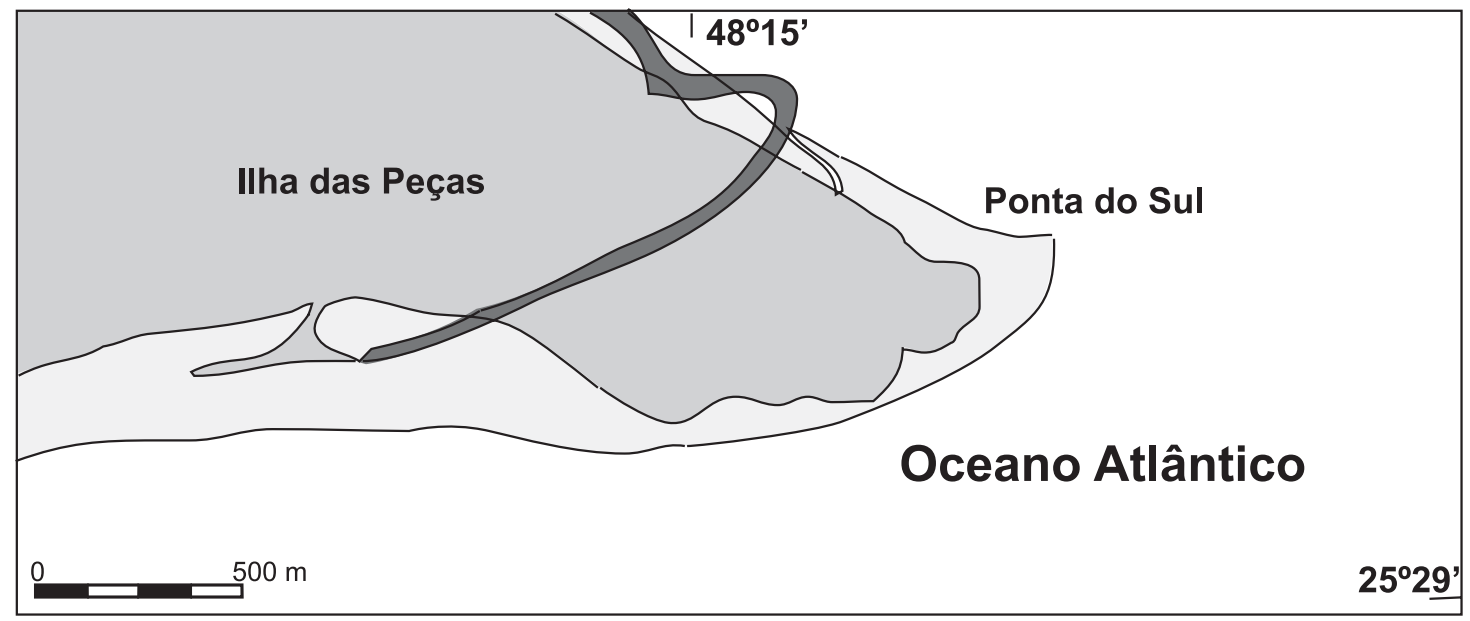

Planície costeira

Praia em 30/06/1952

Praia em 01/08/1955 


\section{Os municípios do litoral do Paraná}

Do ponto de vista administrativo, o litoral paranaense é formado por sete municípios: Guaraqueçaba, Antonina, Morretes, Paranaguá, Pontal do Sul, Matinhos e Guaratuba. Até meados do século XVII, a área total pertencia ao estado de São Paulo, tendo-se desmembrado Paranaguá, em 1648, e sucessivamente os restantes deste, sendo o último Pontal do Paraná, em 1997. São municípios muito próximos a Curitiba, a capital do estado: Antonina, o mais próximo, dista $63 \mathrm{~km}$ de Curitiba, e o mais longe, Guaraqueçaba, $158 \mathrm{~km}$. Antonina e Morretes, localizados no fundo da Baía de Paranaguá, não alcançam o mar aberto, e Matinhos é o único que tem costa exclusivamente para mar aberto. De extensão bastante desigual, Matinhos é o menor, com $111,5 \mathrm{~km}^{2}$ (2\% do total litorâneo); e o maior, Guaraqueçaba, com 2.159,3 km² (35\% do total) (PIERRI, 2003) (Quadro 1; Figura 8).

O espaço e a população permanente estão distribuídos de forma muito desigual, apresentando densidades municipais bem diferentes. Paranaguá, com apenas $11 \%$ da superfície total, concentra 54\% dos habitantes (127.339), e Guaraqueçaba, com $35 \%$ da superfície total, tem apenas $4 \%$ da população ( 8.288 habitantes). A densidade populacional média é de $38 \mathrm{hab} / \mathrm{km}^{2}$, mas varia entre $4 \mathrm{hab} /$ $\mathrm{km}^{2}$, em Guaraqueçaba, e $217 \mathrm{hab} / \mathrm{km}^{2}$, em Matinhos, seguido por Paranaguá, com 191 hab/km² (PIERRI, 2003) (Quadro 1).

\section{Histórico da ocupação do litoral e a conforma- ção dos usos atuais do solo}

Até onde há registros, a ocupação do que hoje constitui o litoral paranaense se iniciou há aproximadamente 6.000 anos pelo homem do sambaqui, como atestam quase três centenas de sambaquis da região (MARTIN et al., 1988; PARELLADA; GOTTARDI NETO, 1994). Estes monumentos, construídos principalmente com conchas, e cujas funções ainda não estão totalmente esclarecidas, apresentam uma forte relação com a costa. Eles estão localizados nas costas estuarinas e próximos à linha de costa da época de sua construção. Processos de sedimentação e variações do nível do mar desde a época de sua construção os deixaram freqüentemente longe da costa atual. As espécies de conchas dos moluscos utilizadas para a construção dos sambaquis atestam a relação dos seus construtores com os estuários ou baías. Quando os europeus chegaram às costas paranaenses, a cultura do homem do sambaqui estava extinta e a região estava ocupada pelos índios carijós, pertencentes à grande família Tupi-Guarani (BIGARELLA, 1999). Os relatos históricos informam que os carijós tinham intensa relação com a costa, principalmente por meio da pesca (IPARDES, 2001).

A ocupação européia do Paraná iniciou-se no século XVI pelo litoral, impulsionada pela exploração de ouro de aluvião. Os primeiros informes datam de 1530 e relatam que do povoamento de São Vicente, no litoral de São Paulo, saíram numerosas expedições em busca de ouro e de

QUADRO 1 - CARACTERIZAÇÃO GERAL DOS MUNICÍPIOS DO LITORAL DO PARANÁ, 2000

\begin{tabular}{|l|c|c|r|r|r|}
\hline \multicolumn{1}{|c|}{ MUNICÍPIO } & $\begin{array}{c}\text { ANO } \\
\text { INSTALAÇÃo }\end{array}$ & $\begin{array}{c}\text { DISTÂNCIA } \\
\text { CAPITAL (km) }\end{array}$ & ÁREA(km $\left.{ }^{2}\right)$ & $\begin{array}{c}\text { POPULAÇ̃̃o } \\
\mathbf{( 2 0 0 0 )}\end{array}$ & $\begin{array}{c}\text { DENSIDADE } \\
\text { DEMOGRÁFICA } \\
\text { (2000) }\end{array}$ \\
\hline Paranaguá & 1648 & 84 & 665,8 & 127339 & 191 \\
\hline Guaratuba & 1947 & 111 & $1.326,8$ & 27257 & 21 \\
\hline Antonina & 1857 & 63 & 968,8 & 19174 & 22 \\
\hline Morretes & 1841 & 65 & 686,5 & 15275 & 4 \\
\hline Guaraqueçaba & 1947 & 158 & $2.159,3$ & 8288 & 217 \\
\hline Matinhos & 1968 & 103 & 111,5 & 24184 & 66 \\
\hline $\begin{array}{l}\text { Pontal do } \\
\text { Paraná }\end{array}$ & 1997 & 112 & 216,2 & 14323 & 38 \\
\hline TOTAL & -- & -- & $6.134,4$ & 235.840 & \\
\hline
\end{tabular}

FONTE: IBGE (2001); PIERRI (2003). 
FIGURA 8 - LITORAL DO ESTADO DO PARANÁ: MUNICÍPIOS, PRINCIPAIS ACESSOS E FEIÇÕES GEOGRÁFICAS

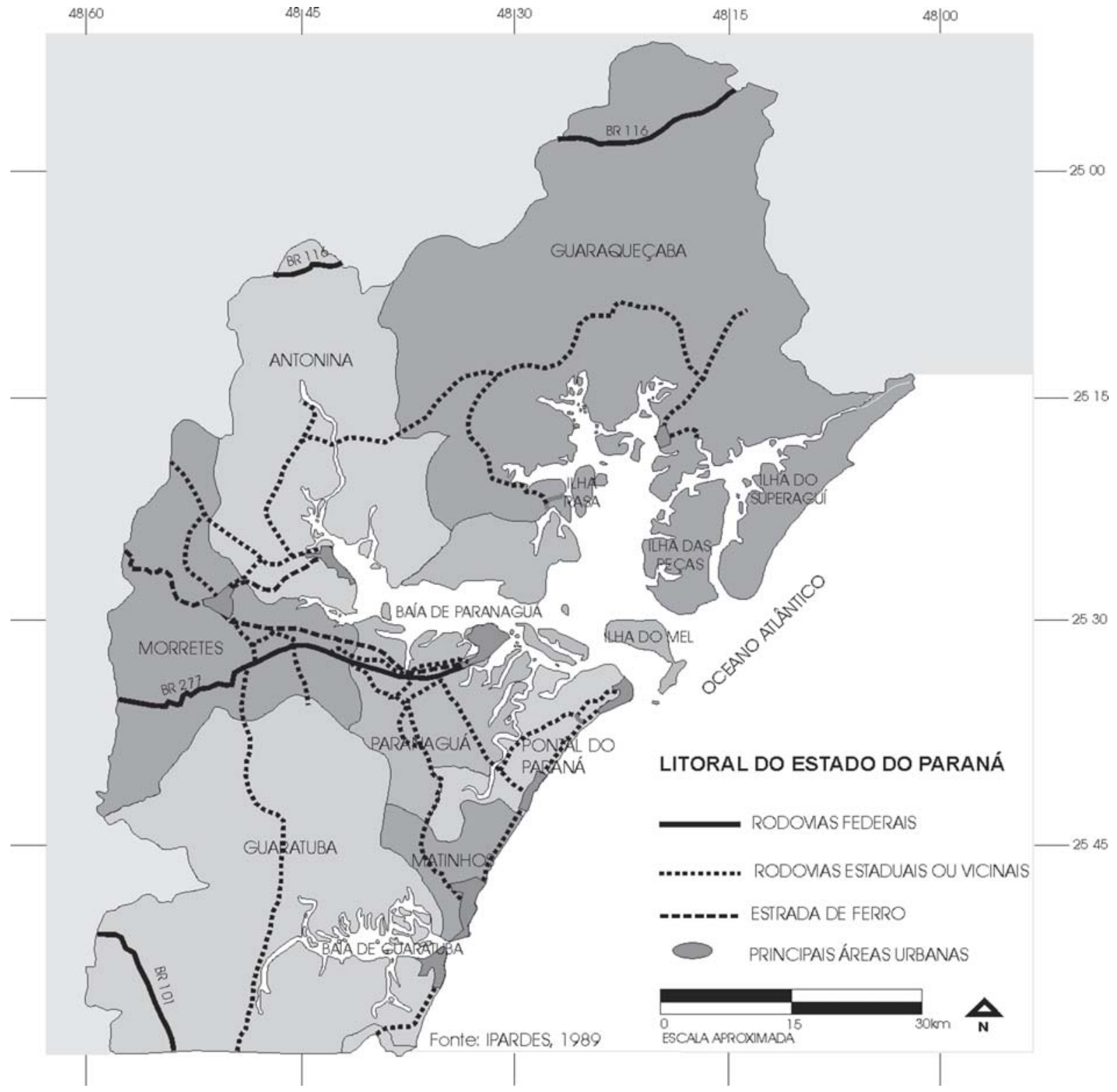

FONTE: Ipardes, 1989, apud Andriguetto Filho et al., 2005.

aprisionamento de índios. Navegaram pelas baías paranaenses e nos rios que nelas deságuam, chegando a ultrapassar a Serra do Mar. No litoral, os colonos estabeleceram-se em Superagüi e na Ilha da Cotinga; e posteriormente ocorreu o povoamento nas margens do rio Itiberê, que daria origem à cidade de Paranaguá, fundada oficialmente em 1648. Existem dados que constatam que Antonina já estava povoada em 1712. O crescimento populacional nessas vilas estimulou a produção de alimentos e de utensílios (BIGARELLA, 1999; IPARDES, 2001). 
Observa-se que o padrão de ocupação das vilas da ilha da Cotinga e da margem do rio Itiberê procurava uma localização funcional à economia e meios de transporte da época, no caso, no interior da baía, que as protegesse das ondas do mar e estivesse próxima a canais da baía favoráveis à navegação.

O processo histórico posterior mostra que as atividades econômicas associadas a certas regiões foram mudando, e isso pautou as formas e ritmos da ocupação e uso do solo, e as mudanças na dinâmica populacional.

Segundo pesquisa desenvolvida por $\mathrm{Miguel}^{2}$ (apud RAYNAUT et al., 2002; MIGUEL apud ANDRIGUETTO FILHO, 2003), o litoral foi a região do Paraná mais desenvolvida economicamente até o início do século XIX. Depois do primeiro momento centrado na produção de ouro, a economia se centrou na produção agrícola, e foi o litoral norte a área mais dinâmica.

Ao fim do século XVIII, o litoral prosperou com a produção de café, arroz e açúcar, e no começo do século XIX com a exportação da erva-mate, dando lugar a um período de grande prosperidade econômica. Crescem também as exportações de arroz, farinha de mandioca e madeira. A pesca era uma atividade importante e difundida, tanto para autoconsumo quanto venda (MIGUEL apud RAYNAUT et al., 2002; MIGUEL apud ANDRIGUETTO FILHO, 2003).

No início do século XIX, as regiões de planalto do Paraná começam a suplantar o litoral, econômica e demograficamente, especialmente com o deslocamento do beneficiamento do mate para o primeiro. Na segunda metade desse século, a produção agrícola do litoral entra em crise, em função da perda de vantagens comparativas em relação a outras regiões do país e do mundo e, mais no final, da abolição da escravatura (MIGUEL apud RAYNAUT et al., 2002; MIGUEL apud ANDRIGUETTO FILHO, 2003).

Mas uma circunstância externa favorável, a demanda de banana de Argentina e Uruguai, favoreceu, tempo depois, a reorganização da agricultura de queimada, abrindo um ciclo de grande prosperidade, com produção também de mandioca e arroz. Essa prosperidade atraiu muitos imigrantes para o litoral norte, que viveu, até aproximadamente 1930, um crescimento econômico inédito, e dupli- cou a população entre 1890 e 1910 (MIGUEL apud RAYNAUT et al., 2002; MIGUEL apud ANDRIGUETTO FILHO, 2003).

A partir de 1930, o sistema de cultura de queimadas entrou em crise, por diversos fatores. Por um lado, a intensificação do uso do solo desdobrou em perda de produtividade e dos rendimentos agrícolas. Por outro, perdeu-se a preferência dos demandantes externos, que passaram a comprar no litoral paulista, porque oferecia preços mais competitivos. Também as iniciativas de desenvolvimento confirmaram sua preferência pelo planalto.

Perante essa crise, ensaia-se a produção de mandioca, de farinha e a extração e comercialização de palmito, que no entanto não permitiram superá-la, e a agricultura ficou limitada quase que exclusivamente à subsistência ou ao mercado local. Isto levou a um progressivo esvaziamento das áreas rurais, gerando um fluxo migratório para as vilas ribeirinhas e para Paranaguá. Muitos agricultores se voltavam mais para a pesca e esta começou a ganhar maior importância, orientando-se cada vez mais ao mercado regional (Paranaguá e Curitiba). Em Morretes, a partir dos anos 1950 , as atividades agrícolas e pastoris das serras foram abandonadas, e os produtores passaram a ocupar as áreas úmidas das planícies, com pecuária e outros cultivos (MIGUEL apud RAYNAUT et al., 2002; MIGUEL apud ANDRIGUETTO FILHO, 2003).

No final dos anos 1960, políticas fiscais incentivaram as atividades agroflorestais, dando lugar à constituição de grandes latifúndios com exploração de madeira e palmito, cultivo de café e criação de búfalos. Até o início dos anos 1980, isso estimulou o desmatamento de vastas áreas de floresta e a expulsão de grande quantidade de agricultores (MIGUEL apud RAYNAUT et al., 2002; MIGUEL apud ANDRIGUETTO FILHO, 2003).

Em Morretes, na década de 1980, agudizaram-se os problemas de falta de competitividade da produção de mandioca e banana, perante a concorrência de Guaratuba, Santa Catarina e São Paulo. Em função disso, houve uma progressiva substituição do sistema tradicional de cultivo por sistemas mais tecnificados, aplicados ao cultivo de gengibre e olericultura, mas que geram diversos impactos ambientais negativos. No último período, Morretes desenvolveu

\footnotetext{
MIGUEL, L. A. Formation, évolution et transformation d'un système agraire dans le sud du Brésil (littoral nord de l'État du Paraná). Une paysannerie face à une politique de protection de l'environnement: “Cronique d'une mort annoncée?". These (Doctorat) - Institut National Agronomique Paris-Grignon, 1997. 313 p. + annexes.
} 
um perfil turístico que explora com bastante sucesso os atrativos de sua cidade histórica, os pratos regionais e o artesanato local (RODRIGUES et al., 2002/2003).

A partir dos anos 1980, os governos federal e estadual implantaram uma política de proteção da natureza que consistiu em criar unidades de conservação, regulamentar certas atividades agrícolas e pesqueiras, e dar incentivos para o plantio de palmito nativo. Por um lado, isto estimulou novas atividades e práticas agrícolas para compensar as limitações impostas (como o processamento da banana e da mandioca), mas, por outro, aumentou o uso de agroquímicos, a extração ilegal de palmito nativo, a introdução de espécies exóticas de palmito e o desmatamento clandestino. Também se promulgaram leis para proteger recursos da baía, e se regulamentou a atividade da pesca em termos de locais, técnicas, volume de captura e calendário (RAYNAUT et al., 2002).

Nesse processo, o município de Guaraqueçaba teve $82 \%$ de sua superfície decretada área de conservação, impondo fortes limites ao uso dos recursos naturais. Economicamente, este município mantém um perfil agropecuário, explorando banana, mandioca e gado, dos quais somente este último encontra condições favoráveis de mercado, mas é a atividade que gera os maiores impactos ambientais e os menores benefícios distributivos. Também tem lugar extração clandestina de palmito nativo, cujo benefício não é retido majoritariamente pela população local, por conta da operação de intermediários. A falta de alternativas e a pobreza relativa presente no município pressionam movimentos migratórios do interior para a costa, acrescentando a população que tenta sobreviver da pesca, e também a migração para outros municípios, principalmente Paranaguá, que é o pólo regional (IPARDES, 2001; RODRIGUES et al., 2002/ 2003).

A atividade portuária tem sido o eixo central das economias dos municípios de Antonina e Paranaguá. Desde o século XVIII, rivalizaram por ganhar a função portuária principal. Antonina conquistou primeiro essa condição porque, sendo a cidade mais próxima a Curitiba, ganhou primeiro a conexão terrestre com o planalto mediante uma rodoviária, à qual se somou depois uma ferrovia. Teve sua fase de auge na década de 1920, quando foi o quarto porto exportador brasileiro graças aos ciclos da madeira, do café e da erva-mate. Contudo, as mudanças na economia mundial após a segunda Guerra Mundial e o fim do ciclo da erva-mate determinaram o declínio da economia da cidade e das atividades de seu porto. No início da década de 1970, com o avanço da produção de soja para exportação, os investimentos se desviaram para o porto de Paranaguá, que ganhou as conexões terrestres necessárias e adequou a profundidade do canal marítimo para possibilitar o acesso dos navios graneleiros mais modernos. Foi assim que o porto de Paranaguá substituiu Antonina como principal porto do estado. Enquanto Antonina entrou numa fase de decadência, Paranaguá se constituiu no porto maior do Sul do Brasil, e o primeiro em exportação de grãos de América do Sul (APPA, 2006; PIERRI, 2003).

A partir dos anos 50 do século XX, e mais intensamente dos 60 e 70, teve lugar o estabelecimento dos balneários ao longo da orla sul, que compreende os atuais municípios de Pontal do Paraná, Matinhos e Guaratuba (ver SAMPAIO, neste mesmo volume). Isto tem raízes que remetem ao contexto econômico geral do chamado estado de bem-estar que fez das classes trabalhadoras - médias e baixas - consumidores com capacidade de adquirir bens duráveis e financiar atividades de lazer para ocupar o tempo livre conquistado como um direito. Culturalmente, a praia, em vez de ser considerada um local perigoso e insalubre, passou a ser valorizada como um ambiente esteticamente belo, e propício para desenvolver atividades de lazer que têm a grande vantagem de serem gratuitas, tais como os banhos de mar e de sol, a pesca esportiva, entre outros. Constataram-se ações por parte do governo estadual que melhoraram as condições de salubridade, e construiu-se uma estrutura viária de acesso, elementos fundamentais para viabilizar esse novo uso do espaço costeiro (SAMPAIO, 2005).

Conformou-se assim, dos anos 1970 para cá, a faixa de ocupação urbana balneária, com a "desordem" própria da voracidade do capital quando descobre uma nova oportunidade de lucro. Tratou-se de uma urbanização acelerada que desconsiderou as condicionantes físicas, gerando diversos problemas ambientais, e que não deu tempo para montar a infra-estrutura e serviços necessários de maneira a garantir condições básicas de saúde pública e qualidade de vida, tanto para os turistas como para a população permanente (SAMPAIO, 2005; PIERRI, 2003). 


\section{Dimensão atual dos principais usos do espaço costeiro e suas condicionantes físicas}

\section{O uso portuário}

A história do litoral paranaense, como foi dito, teve seu início com o uso portuário. Seus complexos estuarinos, principalmente o de Paranaguá, possibilitaram a implantação de portos abrigados; inicialmente, na ilha da Cotinga, e posteriormente, em Paranaguá e Antonina. A presença de barras - bancos de areias próximos às desembocaduras era o principal obstáculo à navegação.

Posteriormente, as características naturais, as tendências históricas de ocupação e a legislação ambiental, que foi sendo implantada nas últimas décadas do século XX, originaram uma configuração bastante particular na baía de Paranaguá: um complexo estuarino dividido numa parte norte, definida como área de proteção ambiental, e uma parte sul, com uso intensivo portuário. Certamente, os fluxos naturais não devem respeitar esta divisão. ${ }^{3}$

O porto de Paranaguá, que tem um cais público e terminais privados, apresenta-se como um dos principais do país na movimentação de cargas, e é líder em exportação de soja, em grão e farelo. Os tipos principais de cargas movimentadas são: contêineres, carga geral (congelados, madeira, papel e celulose, açúcar em sacos e diversos) e granéis sólidos (fertilizantes, soja e farelos, trigo, milho e açúcar). A sua área de influência compreende o estado do Paraná e parte dos estados de São Paulo, Santa Catarina, Rio Grande do Sul e Mato Grosso do Sul. Inclui também o
Paraguai, que dispõe de um entreposto franco no porto (MINISTÉRIO DOS TRANSPORTES, 2006).

Paranaguá vem apresentando um aumento na movimentação de cargas ao longo da última década. Em 2000, o Porto de Paranaguá movimentou um total de 21.345.734 toneladas de cargas, enquanto em 2004 tinha crescido para 32.566.882, registrando um crescimento anual sistemático. Por sua parte, os portos de Antonina também cresceram em movimentação, passando de 247.216 toneladas, em 2000, a 1.085.693, em 2004. Na comparação, a operação dos portos de Antonina representa apenas 1,2\% do total movimentado por ambos, em 2000, e 3,3\% do total de 2004. Ou seja, a participação dos portos de Antonina é, em comparação ao porto de Paranaguá, muito baixa, mas registra um crescimento relativo maior (Quadro 2) (ANTAQ, 2006)

Em ambos os portos, o embarque de cargas tem maior importância em relação ao desembarque, com exceção do Porto de Antonina em 2001 (Quadro 3) (ANTAQ, 2006).

Com relação ao tipo de navegação, diferencia-se a de cabotagem, realizada entre portos do território brasileiro por via marítima ou vias navegáveis interiores, daquela de longo curso, realizada entre portos brasileiros e portos estrangeiros. A navegação mais expressiva, em ambos os portos, é a de longo curso, representando mais de $90 \%$ do movimento de cargas no período de 2000 a 2004 (Quadro 4) (ANTAQ, 2006). Isso indica que a principal função dos portos paranaenses é escoar a produção da sua área de influência, majoritariamente para a exportação, antes que a de receber mercadorias para supri-la.

O progressivo aumento do comércio internacional exige a expansão das áreas portuárias e o aprofundamento dos canais de acesso aos portos, sendo essa uma tendência for-

QUADRO 2 - EVOLUÇÃO DA MOVIMENTAÇÃO GERAL DE CARGAS NOS PORTOS ORGANIZADOS ETERMINAIS DE USO PRIVATIVO - 2000-2004 (EM TONELADAS E \%)

\begin{tabular}{|lr|l|l|l|l|l|}
\hline Porto & $\mathbf{2 0 0 0}$ & $\mathbf{2 0 0 1}$ & $\mathbf{2 0 0 2}$ & $\mathbf{2 0 0 3}$ & $\mathbf{2 0 0 4}$ \\
\hline Antonina & 247.216 & 538.270 & 636.273 & 1.025 .476 & 1.085 .693 \\
\hline & $\%$ & 1,2 & 1,9 & 2,2 & 3,1 & 3,3 \\
\hline Paranaguá & 21.107 .518 & 28.262 .219 & 27.859 .879 & 32.499 .953 & 31.481 .189 \\
\hline & $\%$ & 98,8 & 98,1 & 97,8 & 96,9 & 96,7 \\
\hline Total & \% & 21.354 .734 & 28.800 .489 & 28.496 .152 & 33.525 .429 & 32.566 .882 \\
\hline \multicolumn{2}{|r|}{100} & 100 & 100 & 100 & 100 \\
\hline
\end{tabular}

FONTE: ANTAQ, 2006.

Por exemplo, no acidente com o navio Vicuña, em 2004, que explodiu e derramou óleo na baía, este rapidamente se deslocou em direção à desembocadura pelas correntes de maré vazante, mas, a seguir, para o norte, pela baía das Laranjeiras, movido pelos ventos e pelas correntes de maré enchente. Ou seja, da área portuária para a área de proteção ambiental. 
QUADRO 3 - EVOLUÇÃO DO EMBARQUE E DESEMBARQUE DE CARGAS NOS PORTOS ORGANIZADOS E TERMINAIS DE USO PRIVATIVO DE PARANAGUÁ EANTONINA, POR SENTIDO - 2000-2004 (EM TONELADAS)

\begin{tabular}{|c|c|c|c|c|c|}
\hline Porto/sentido & 2000 & 2001 & 2002 & 2003 & 2004 \\
\hline \multicolumn{6}{|l|}{ Antonina } \\
\hline Desembarque & 74.536 & 447.465 & 252.012 & 386.302 & 512.097 \\
\hline Embarque & 172.680 & 90.805 & 384.261 & 639.174 & 573.596 \\
\hline \multicolumn{6}{|l|}{ Paranaguá } \\
\hline$\overline{\text { Desembarque }}$ & 6.448 .659 & 6.104 .271 & 6.326 .400 & 8.723 .368 & 8.447 .852 \\
\hline Embarque & 14.658 .859 & 22.157 .948 & 21.533 .479 & 23.776 .585 & 23.033 .337 \\
\hline Total & 21.354 .734 & 28.800 .489 & 28.496 .152 & 33.525 .429 & 32.566 .882 \\
\hline
\end{tabular}

FONTE: ANTAQ, 2006.

QUADRO 4 - EVOLUÇÃO DA MOVIMENTAÇÃO GERAL DE CARGAS, NOS PORTOS ORGANIZADOS E TERMINAIS DE USO PRIVATIVO DE PARANAGUÁ E ANTONINA, NAS NAVEGAÇÕES DE LONGO CURSO E CABOTAGEM - 2000-2004 (EM TONELADAS)

\begin{tabular}{|c|c|c|c|c|c|}
\hline Porto/navegação & 2000 & 2001 & 2002 & 2003 & 2004 \\
\hline Antonina/LC & 203.898 & 496.982 & 406.873 & 1.025 .476 & 1.085 .693 \\
\hline Antonina/cabotagem & 43.318 & 41.288 & 229.400 & - & - \\
\hline Paranaguá/LC & 18.997 .164 & 26.275 .011 & 25.596 .004 & 29.604 .420 & 29.012 .828 \\
\hline Paranaguá/cabotagem & 2.110 .354 & 1.987 .208 & 2.263 .875 & 2.895 .533 & 2.468 .361 \\
\hline Total & 21.354 .734 & 28.800 .489 & 28.496 .152 & 33.525 .429 & 32.566 .882 \\
\hline
\end{tabular}

FONTE: ANTAQ, 2006.

te que configurará um uso portuário mais extenso e mais intenso do litoral paranaense nos próximos anos, com incremento de riscos, impactos e conflitos.

Os portos de Antonina e Paranaguá deverão expandir suas áreas de retroporto e de acostamento, e ampliar e melhorar suas vias de escoamento de mercadorias, seja por terra, com ampliação de estradas e ferrovias, seja por mar, aumentando o calado dos canais de acesso. Devem-se expandir ao longo da margem sul da baía. Uma das dificuldades de expansão está relacionada à ocorrência de manguezais ao longo da costa. A construção de cais poderá exigir a retirada dessa vegetação, o que deve implicar negociações e compensações ambientais para ser efetivado. Em conjunto, os impactos das atividades portuárias devem aumentar. Dita expansão alcançará a Ponta do Poço, em Pontal do Sul, que é uma área muito favorável para ocupação portuária pelo seu grande calado natural e não tem se consolidado por causa da falta de vias adequadas para o transporte terrestre das mercadorias, mas já existem projetos que deverão resolver essa restrição.
Com o aumento do calado dos navios, houve necessidade de dragar canais artificiais, tanto dentro do estuário como nos bancos de areia das barras. Estes canais de navegação interferem na dinâmica de sedimentos na zona costeira. O fluxo de sedimentos que se movimenta ao longo da costa foi interrompido pelos canais escavados nas barras, provocando alterações importantes das costas próximas, principalmente processos erosivos a jusante da deriva predominante (ANGULo et al., 2006). Ademais, o material dragado foi despejado inadequadamente. A grande área acrescida na ilha do Mel, nos últimos 25 anos, próxima ao Farol das Conchas, provavelmente é decorrente do despejo em áreas rasas das areias dragadas na parte externa do canal que dá acesso ao porto de Paranaguá (GIANNINI et al., 2004; ANGULO et al., 2006) (Figura 9).

Até recentemente, as atividades de dragagem e despejo do material dragado têm sido abordadas como atividades com um único fim, que é o de manter os canais de navegação seguros, desconsiderando todos os impactos ambientais e as interferências com outras atividades. Deste 


\section{FIGURA 9 - ÁREA ACRESCIDA DA ILHA DO MEL ENTRE 1980 E 2005 (A). LINHA DE COSTA EM 1980 (LINHA VERMELHA)}

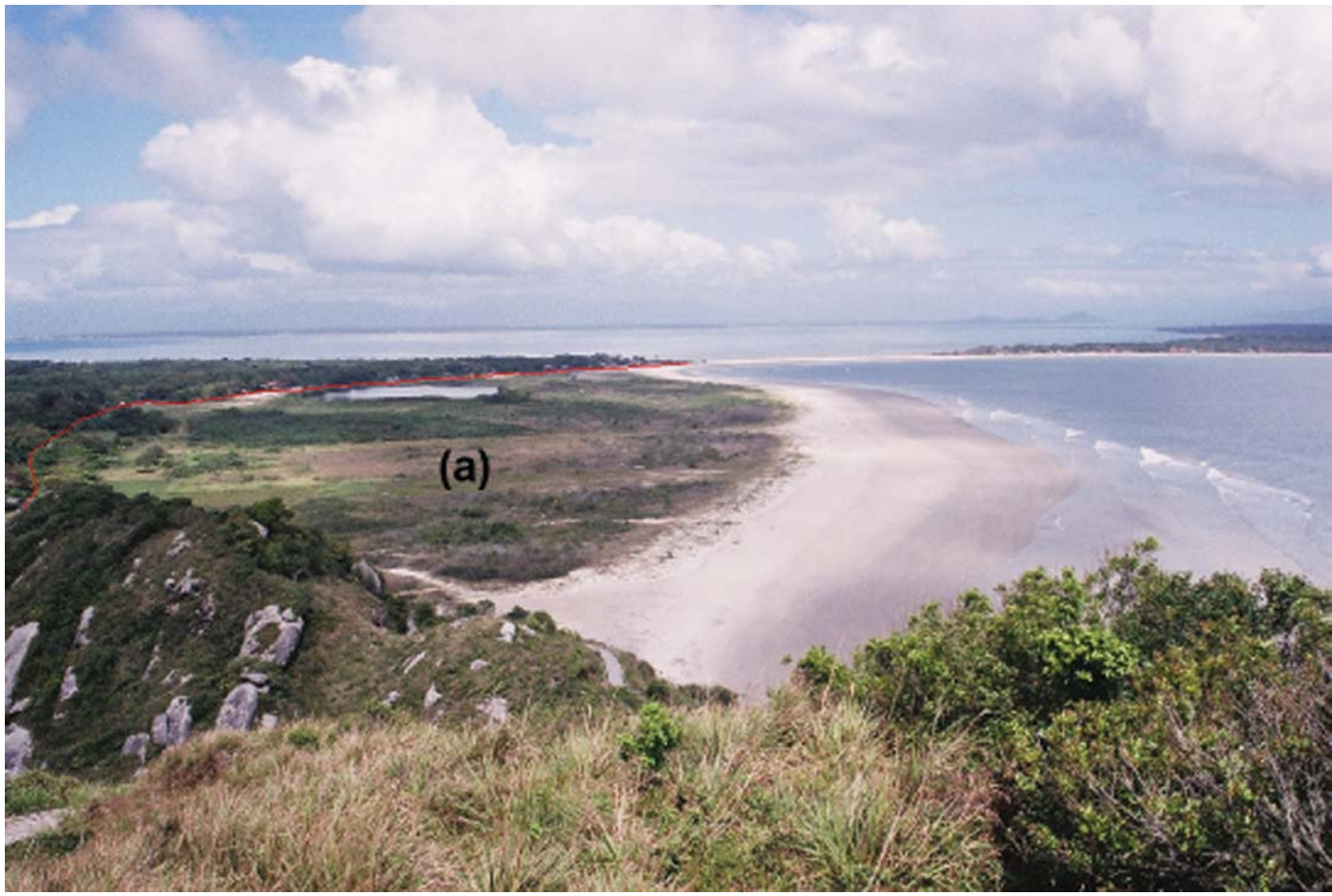

modo, é necessário criar um programa integrado que considere os impactos ambientais nas áreas de influência e a possibilidade de utilização dos sedimentos dragados como matéria-prima ou fonte de sedimentos para costas próximas com problemas de erosão, isto é, que o material dragado possa ser utilizado para a alimentação artificial de praias.

\section{Uso para conservação da natureza}

O litoral do Paraná tem uma riqueza natural destacada. Tem a maior área contínua de Floresta Pluvial Atlântica ainda preservada, de alto valor ambiental pela grande biodiversidade, e que é parte da Reserva da biosfera de Mata Atlântica formalizada pela Unesco. Apresenta também outros ecossistemas, com nove diferentes unidades ambientais naturais continentais, segundo morfologia e vegetação (LIMA et al., 1998; ANDRIGUETTO FILHO; MARCHIORO, 2002).
Em parte como reconhecimento do anterior, atualmente o litoral tem $82 \%$ de sua área voltada para a conservação. Trata-se de unidades de conservação (em diante, UCs) federais e estaduais, sendo as maiores a APA de Guaraqueçaba e a APA de Guaratuba. A vontade política de conservar foi exercida, em grande proporção, sob áreas de Floresta Atlântica marginalizadas economicamente, seja por dificuldades de acesso e/ou por não apresentar - ou ter perdido - interesse econômico-produtivo. Isso, em um sentido, fez mais fácil a decisão formal de criar as UCs por não estar subtraindo recursos a grupos econômicos fortes, mas, ao mesmo tempo, essa circunstância redobrou as dificuldades de conquistar ou manter condições de sustentabilidade econômica e social para a população que mora dentro delas ou em suas áreas de amortecimento. Este fato faz com que a conservação e seus agentes apareçam como responsáveis pela pobreza e falta de oportunidades, pelo atraso e pela emigração existentes nessas áreas, sem lembrar que as restrições de uso impostas vieram muitas vezes apenas 
reforçar os limites já existentes para o desenvolvimento, e não tanto criá-los, como muitas vezes se interpreta. O mercado criou antes, e continua reproduzindo, grande parte da insustentabilidade social dessas regiões (RODRIGUES et al., 2002/2003).

O Quadro 5 mostra o detalhe das UCs presentes em cada município do litoral do Paraná, discriminando o nível de gestão ao qual estão submetidas (federal ou estadual) e sua superfície.

De modo complementar, o Quadro 6 apresenta a área total dos municípios, o porcentual coberto por UCs e o valor de ICMS Ecológico repassado pelo Estado para estes.

Observa-se que os municípios que têm maior área total são os que têm o maior porcentual de sua área coberto

QUADRO 5 - UNIDADES DE CONSERVAÇÃO DOS MUNICÍPIOS DO LITORAL DO PARANÁ SEGUNDO NÍVEL DE GESTÃO (FEDERAL OU ESTADUAL) E ÁREA(HA E \%) - 2006

\begin{tabular}{|c|c|c|c|c|}
\hline Município & $\overline{\mathrm{UC}}$ & Nível de gestão & Área (ha) & \% Área \\
\hline \multirow[t]{7}{*}{ Antonina } & APA de Guaraqueçaba & Federal & $50.529,30$ & 64,5 \\
\hline & Parque Estadual Roberto Ribas Lange & Estadual & $1.009,37$ & 1,3 \\
\hline & AEIT do Marumbi & Estadual & $22.740,63$ & 29,0 \\
\hline & Parque Estadual do Pico Paraná & Estadual & $2.253,00$ & 2,9 \\
\hline & RPPN Res. Natural Morro da Mina & Estadual & $1.336,19$ & 1,7 \\
\hline & RPPN Águas Belas & Estadual & 508,2 & 0,6 \\
\hline & Subtotal & & $78.376,69$ & 100 \\
\hline \multirow[t]{6}{*}{ Guaraqueçaba } & Estação Ecológica de Guaraqueçaba & Federal & $13.638,90$ & 6,5 \\
\hline & Parque Nacional do Superagüi & Federal & $34.362,00$ & 16,4 \\
\hline & APA de Guaraqueçaba & Federal & $160.125,64$ & 76,5 \\
\hline & RPPN Salto do Morato & Federal & 819,18 & 0,4 \\
\hline & RPPN Quatro Quedas do Sebuí & Federal & 400,78 & 0,2 \\
\hline & Subtotal & & $209.346,5$ & 100 \\
\hline \multirow[t]{2}{*}{ Guaratuba } & APA de Guaratuba & Estadual & $130.663,53$ & 100 \\
\hline & Subtotal & & $130.663,53$ & 100 \\
\hline \multirow[t]{3}{*}{ Matinhos } & Parque Estadual do Rio da Onça & Estadual & 109,50 & 3,6 \\
\hline & APA de Guaratuba & Estadual & $2.953,63$ & 96,4 \\
\hline & Subtotal & & $3.063,13$ & 100 \\
\hline \multirow{7}{*}{ Morretes } & Parque Estadual da Graciosa & Estadual & $1.189,58$ & 3,3 \\
\hline & Parque Estadual Pico do Marumbi & Estadual & $2.342,41$ & 6,5 \\
\hline & APA de Guaratuba & Estadual & $12.593,83$ & 34,7 \\
\hline & AEIT do Marumbi & Estadual & $17.576,60$ & 48,4 \\
\hline & Parque Estadual do Pau Oco & Estadual & 905,58 & 2,5 \\
\hline & Parque Estadual Roberto Ribas Lange & Estadual & $1.689,32$ & 4,7 \\
\hline & Subtotal & & $36.296,49$ & 100 \\
\hline \multirow[t]{8}{*}{ Paranaguá } & Reserva Indígena Ilha da Cotinga & Federal & $1.685,04$ & $\overline{4,5}$ \\
\hline & APA de Guaraqueçaba & Federal & $26.252,50$ & 69,4 \\
\hline & Estação Ecológica da Ilha do Mel & Estadual & $2.240,69$ & 5,9 \\
\hline & Estação Ecológica do Guaraguaçu & Estadual & $1.145,00$ & 3,0 \\
\hline & APA de Guaratuba & Estadual & $5.657,40$ & 15,0 \\
\hline & Floresta Estadual do Palmito & Estadual & 525,00 & 1,4 \\
\hline & Parque Estadual da Ilha do Mel & Estadual & 335,84 & 0,9 \\
\hline & Subtotal & & $37.841,47$ & 100 \\
\hline \multirow{2}{*}{$\begin{array}{l}\text { Pontal do } \\
\text { Paraná }\end{array}$} & Estação Ecológica do Guaraguaçu & Estadual & $2.265,71$ & 100 \\
\hline & Subtotal & & $2.265,71$ & 100 \\
\hline \multicolumn{2}{|l|}{ TOTAL } & --- & $497.853,52$ & --- \\
\hline
\end{tabular}

(*) Exclusive a AEIT Pinheiro e Pinheirinho e o Parque Nacional Saint Hilaire / Lange. FONTE: IAP, 2006. 
por UCs: Guaratuba $(98,5 \%)$ e Guaraqueçaba $(96,9 \%)$. Antonina também apresenta um porcentual de área com UCs elevado, de 80,9\%. Com relação ao regime de conservação dessas UCs, Guaraqueçaba é o município que tem uma área maior coberta por unidades de uso indireto: 22,9\%, somando as áreas do Parque Nacional do Superagüi e da Estação Ecológica de Guaraqueçaba. Antonina tem 4,2\% de área de uso indireto, e Guaratuba tem uma única unidade de conservação, a APA Estadual de Guaratuba. Entre os municípios com menor porcentual de sua área coberta por UCs estão Pontal do Paraná e Matinhos, com 10,5\% e $27,4 \%$, respectivamente. Também são os municípios com menor área total (IAP, 2006) (Quadro 6).

O repasse de ICMS Ecológico aos municípios mostra aqueles que estão submetidos a um regime mais rígido de conservação, por causa dos critérios estabelecidos para determinar esse valor. ${ }^{4}$ Guaraqueçaba é aquele que recebe o maior montante, de $\mathrm{R} \$ 1.018 .493,88$, pois é o que tem uma área maior submetida a um regime restrito. Em seguida se encontra Antonina, que recebe R \$ 542.912,34; Paranaguá, com R \$ 427.867,43; e Morretes, com R\$ 417.200,78. Esses dois municípios têm um porcentual relativamente menor da sua área voltada para a conservação, de cerca de 50\%, mas abrigam Parques Estaduais e Estações Ecológicas, categorias de UCs mais restritivas. Guaratuba, assim como Matinhos e Pontal do Paraná, está entre os municípios que recebem um repasse menor, apesar de o primeiro ter o maior porcentual da área coberta por UCs. Isso pode acontecer por essa área ser coberta por uma UC da categoria de uso sustentável que, em princípio, garantiria menor proteção ambiental (IAP, 2006).

A questão das UCs não é apenas sua criação, localização, extensão e definição adequada de seu regime. Elas têm o desafio duplo de cumprir a vontade de proteção que a sociedade dita na hora de sua criação, mas também de cuidar da sustentabilidade da população humana que as habita. A implantação e gestão autoritária das UCs, alienada no naturalismo, tem-se mostrado duplamente ineficiente em relação a ambos os objetivos, e por isso a questão deve passar por estratégias que convertam a população local no principal beneficiário das atividades econômicas possíveis, o que fará deles os melhores guardiães dos recursos dos quais dependem. Isso não acontece se a sorte econômica dos moradores locais se deixa livrada à ação espontânea do mercado; são necessários vontade política, recursos e ações concretas para criar as condições necessárias (KIM, 2004).

\section{Uso pesqueiro}

No século XVIII, um dos principais produtos de exportação do Porto de Paranaguá era o peixe seco, e até pelo

QUADRO 6 - SUPERFÍCIE TOTAL, ÁREA COBERTA POR UNIDADES DE CONSERVAÇÃO, E ICMS ECOLÓGICO - MUNICÍPIOS DO LITORAL DO PARANÁ - 2006

\begin{tabular}{|r|r|r|r|}
\hline \hline \multicolumn{1}{|c|}{ Município } & Área (Há) & \% Área com UCs(*) & \multicolumn{1}{c|}{$\begin{array}{c}\text { ICMS Ecológico(**) } \\
\text { (em Reais) }\end{array}$} \\
\hline Antonina & $96.897,71$ & $80,9 \%$ & $542.912,34$ \\
\hline Guaraqueçaba & $209.346,50$ & $96,9 \%$ & $1.018 .493,88$ \\
\hline Guaratuba & $132.688,11$ & $98,5 \%$ & $351.646,49$ \\
\hline Matinhos & $11.156,37$ & $27,4 \%$ & $126.982,48$ \\
\hline Morretes & $68.659,42$ & $52,8 \%$ & $417.200,78$ \\
\hline Paranaguá & $66.583,09$ & $56,8 \%$ & $427.867,43$ \\
\hline \hline Pontal do Paraná & $21.629,45$ & $10,5 \%$ & 42.612 .08 \\
\hline TOTAL & $606.960,65$ & $82,02 \%$ & $2.885 .103,40$ \\
\hline \hline
\end{tabular}

(*)Soma das áreas das UCS utilizadas para o cálculo do ICMS Ecológico/área total do município

(**)em Reais, referente ao mês junho de 2006

FONTE: IAP, 2006.

\footnotetext{
4 Dos $25 \%$ do ICMS arrecadado cujo destino os estados podem decidir, o Estado do Paraná definiu destinar $5 \%$ com um critério ambiental, que é o denominado ICMS Ecológico. Estabeleceu que 2,5\% seriam distribuídos aos municípios que têm mananciais de abastecimento público para municípios vizinhos e os outros $2,5 \%$ aos municípios que têm UCs e Terras Indígenas. É realizada uma avaliação da qualidade da UC que, junto com seu tipo (de uso indireto ou sustentável), seu âmbito de gestão (municipal, estadual ou federal) e domínio (público ou privado), determina níveis bastante variados de ICMS (IAP, 2006).
} 
menos meados do século XIX, a pesca era uma atividade importante na baía de Paranaguá (ANDRIGUETTO FILHO, 1999). No final do século XX, a pesca continua sendo importante, fundamentalmente por ser o meio de produção de alimento e de geração de renda de uma significativa parte da população permanente do litoral.

Segundo Andriguetto Filho et al. (2005), são 4.277 os pescadores profissionais registrados na Secretaria Especial de Pesca (Seap), e eles dispõem de uma frota de 930 embarcações registradas no Ibama. ${ }^{5}$ Considerando o grupo familiar dos pescadores, pode-se estimar que 12 a 15 mil pessoas no litoral estejam dependendo ou sendo beneficiadas por esta atividade. Estes pescadores estão distribuídos em 6 municípios da região (todos, exceto Morretes) de forma desigual: uma quarta parte deles está em Guaraqueçaba (25,6\%), e quase outra quarta parte, em Paranaguá $(23,4 \%)$. Guaratuba concentra 21\%; Antonina, 16,5\%; Pontal, 8,6\%; e Matinhos, 5\% (215) (Quadro 7).

Considerando o peso dos pescadores na população total estimada pelo IBGE para 2006 nesses municípios, um de cada 62 habitantes é pescador. O município que tem perfil mais ligado à pesca é Guaraqueçaba, onde um de cada 8 habitantes é pescador. Numa faixa intermediária estão Antonina, onde um em cada 30 habitantes é pescador, Guaratuba, com um pescador em cada 38 habitantes, e Pontal do Paraná, com um em cada 52 habitantes. Já em Matinhos e Paranaguá essa proporção é bem menor: um em cada 157, e um em cada 148 habitantes é pescador, respectivamente (Quadro 7).

Em pesquisa realizada por Andriguetto Filho (1999) foram identificadas no litoral do Paraná 103 vilas de pescadores: 60 com 5 ou mais domicílios, 23 com menos de 5 domicílios - possivelmente em vias de extinção -, e 20 já extintas. As vilas se distribuem dentro e fora das baías, em ambientes urbanos e rurais. Este autor estudou 22 das vilas com 5 domicílios ou mais, e as classificou em seis tipos de sistemas de produção, considerando a combinação de um conjunto de variáveis. Esses sistemas são:

- Tipo I. Trata-se de um sistema agro-pesqueiro em extinção, em que a agricultura é tanto ou mais importante do que a pesca;

- Tipo II. É o sistema pesqueiro mais tradicional. A embarcação mais comum é a canoa de um pau só, sem motor, e há diversidade em termos de técnicas de pesca. Muitas das vilas onde se localiza são remotas e dependem da intermediação para a comercialização;

- Tipo III. É um sistema intermediário, que trabalha na desembocadura das baías e no mar aberto, com embarcações de tábua e a motor. Utiliza-se da deriva ou fundeio, para peixes e camarão, e de arrasto de fundo, para camarão;

- Tipo IV. É o mais tecnificado e orientado para o mercado. Utiliza barcos maiores e equipamentos

\section{QUADRO 7 - QUANTIDADE E PROPORÇÃO DE PESCADORES NA POPULAÇÃOTOTAL DOS MUNICÍPIOS PESQUEIROS DO LITORAL DO PARANÁ - 2005/2006}

\begin{tabular}{|c|c|c|c|c|c|}
\hline & $\begin{array}{c}\text { População } \\
\text { estimada (IBGE, } \\
\text { 2006) }(*)\end{array}$ & $\%$ & $\begin{array}{l}\text { População de pescadores } \\
\text { (Seap, 2005) }\end{array}$ & $\%$ & $\begin{array}{c}1 \text { pescador a cada } X \\
\text { habitantes }\end{array}$ \\
\hline Antonina & 20.729 & 7,8 & 700 & 16,5 & 30 \\
\hline Guaraqueçaba & 8.677 & 3,3 & 1096 & 25,6 & 8 \\
\hline Guaratuba & 34.100 & 12,9 & 900 & 21,0 & 38 \\
\hline Matinhos & 33.688 & 12,8 & 215 & 5,0 & 157 \\
\hline Paranaguá & 147.934 & 56,1 & 1001 & 23,4 & 148 \\
\hline Pontal do Paraná & 18.848 & 7,1 & 365 & 8,6 & 52 \\
\hline TOTAL & 263.976 & 100 & 4.277 & 100 & 62 \\
\hline
\end{tabular}

(*) Estimativa feita pelo IBGE; (**) Pescadores registrados no DPA/Seap-PR. (Antonina e Guaratuba foram estimados)

FONTE: IBGE, 2006, apud Deschamps, 2007; Seap, apud Andriguetto Filho et al., 2005.

\footnotetext{
Tanto a quantidade de pescadores como de embarcações realmente existentes podem diferir destas cifras, para mais e para menos, por diferentes motivos: por um lado, existe falta de registro de ambas as coisas; por outro, existem pessoas registradas que não são pescadores e que fazem o trâmite para obter os benefícios sociais da categoria.
} 
de comunicação e navegação modernos que permitem viagens de vários dias. O pescado é processado em terra, incluindo o descascamento mecanizado do camarão, filetagem de peixe e congelamento;

- Tipo V. Trata-se da pesca tradicional de arrasto de praia com a tainha como alvo principal. Está em declínio;

- Tipo VI. É característico de vilas urbanas, mais ao sul, com influência catarinense e é intermediário entre os tipos III e IV, em termos de tecnologia (ANDRIGUETTO FILHO, 2003).

É notável que os sistemas se localizam em tipos de costa específicos (Figura 3). Os sistemas I, II e IV se localizam em costas estuarinas, sendo o sistema I o mais interiorizado, o II, localizado numa posição intermediária, e o VI numa posição mais externa. Já o sistema III se localiza no estuário próximo às desembocaduras, e os sistemas V e VI, próximos às desembocaduras ou no mar aberto, evidenciando a influência do meio físico nos sistemas pesqueiros.

Comparando a localização das vilas ou bairros de pescadores com as características morfológicas e dinâmicas da costa, podem ser identificadas algumas relações. A maioria das vilas de pescadores localiza-se dentro dos estuários. Destas, a grande maioria se situa em costas sem manguezais e com fácil acesso das pequenas embarcações aos corpos d'água. Dos $1.300 \mathrm{~km}$ de costa estuarina do Paraná apenas 121 km (9\%) apresentam estas condições, sendo nelas que se constata a clara preferência de ocupação por parte dos pescadores. Nos $1.178 \mathrm{~km}$ restantes, com costa com manguezais, quase não há ocupação. Terrenos moles e inundados duas vezes por dia pela ação das marés claramente não são favoráveis à ocupação; contudo, freqüentemente ocorrem terrenos sem essa limitação à retaguarda dos manguezais que não foram ocupados, sugerindo que a costa com manguezal era indesejada mesmo quando apenas se interpunha entre os corpos d'água e a terra firme.

Apenas em alguns casos foi observado que uma pequena faixa de poucos metros de mangue foi removida para criar condições de atracadouro, por exemplo, na Vila de Maciel, em Pontal do Paraná. É interessante notar que esta barreira à ocupação costeira, em princípio natural, mas que pode ser considerada tecnológica por operar de maneira relativa aos recursos técnicos desta população, vai se consolidar posteriormente, somando uma barreira legal quan- do os manguezais se instituem como áreas de preservação permanente. Por este motivo, atualmente, ainda que o limite tecnológico pudesse ser transposto, a ocupação da costa estuarina permanece fortemente limitada ou condicionada pela ocorrência de manguezais que se interpõem entre a terra firme e os estuários.

Por outro lado, observa-se que diversos tipos de costa estuarina sem manguezais foram ocupados, sejam formadas por terraços de certa altitude ( 2 a 4 metros sobre o nível de maré alta), como são os casos das vilas de Ilha Rasa e Bertioga (Figura 10), sejam formadas por planícies próximas ao nível de maré alta e, conseqüentemente, suscetíveis às inundações por marés meteorológicas, como é o caso da vila de Guapicu (Figura 11), sejam formadas por encostas de morros chegando aos estuários e formando costões rochosos, tal como a vila Canudal, no Superagüi (Figura 12). Nestes casos, as ocupações localizam-se em áreas onde há formação de pequenas praias, bancos lodosos ou marismas, mais favoráveis para as embarcações e menos perigosos para a navegação que os fundos rochosos.

Pode-se concluir que a localização das comunidades pesqueiras tradicionais foi fortemente condicionada pelo tipo de costa, que deveria ser favorável ao acesso das pequenas embarcações, o que limitou grandemente as localizações possíveis das vilas, dada a escassa ocorrência de costas sem manguezais. Do mesmo modo, a ocupação futura da costa paranaense está fortemente restrita pela constituição de extensos setores de costa em áreas de preservação permanente, sob diferentes institutos legais.

\section{Usos turísticos: balneário e navegação de recrea- ção}

Os usos turísticos do solo relacionados à costa são, principalmente, o uso balneário e a navegação de recreação, incluindo a pesca esportiva.

$\mathrm{O}$ uso balneário acarreta dois grandes processos que envolvem populações diferentes e que acontecem em diferentes ritmos, e até certo ponto, em diferentes espaços. Por um lado, a afluência dos turistas, sejam aqueles que constroem suas segundas residências, impulsionando a urbanização mais próxima ao mar e de melhor qualidade, como aqueles que visitam o litoral sem possuir casa própria. Trata-se de uma população de presença concentrada na temporada de verão e feriados próximos, e, em muito menor grau, nos fins de semana do resto do ano. Por outro lado, a 

ÇAS

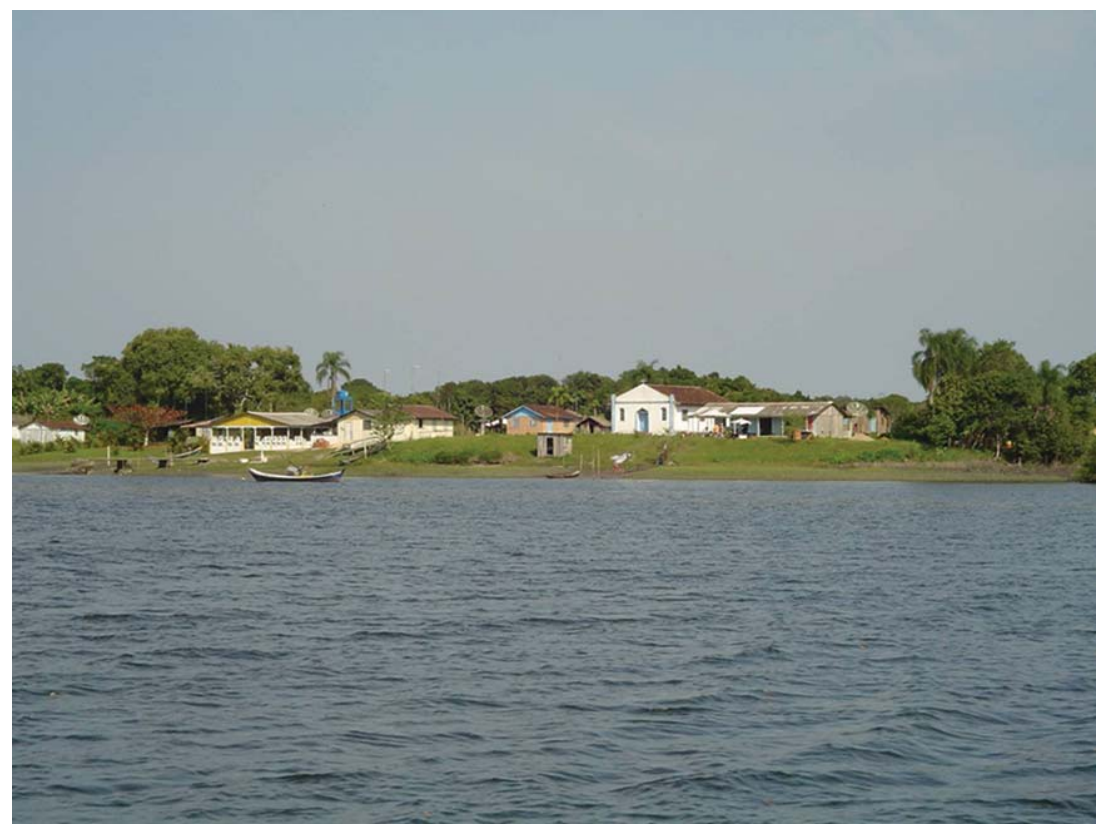

FIGURA 11 - VILA GUAPICU, LOCALIZADA SOBRE PLANÍCIE BAIXA NA ILHA DAS PEÇAS

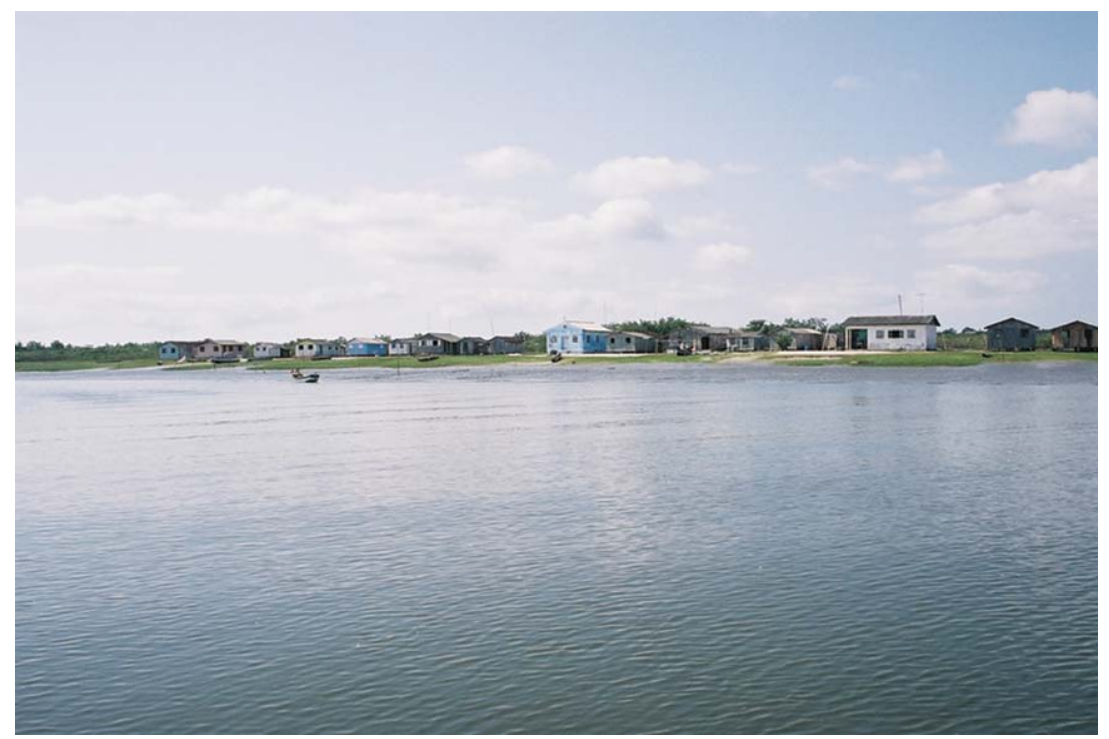




\section{FIGURA 12 - VILA CANUDAL LOCALIZADA NO SOPÉ DE ENCOSTA DE MORRO NO SUPERAGÜI}

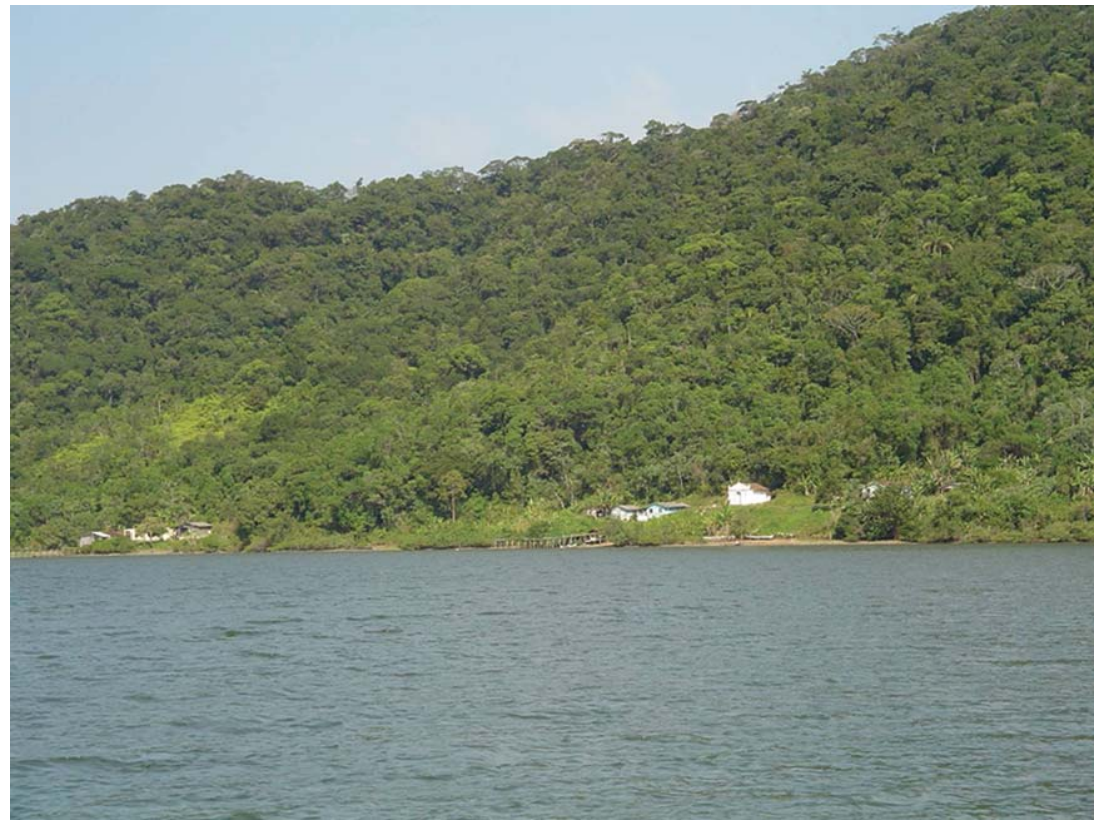

afluência permanente de pessoas que vêm de outras regiões para estabelecer sua moradia no litoral, com expectativas de melhorar sua renda e qualidade de vida, em grande parte pessoas de baixa renda, buscando novas oportunidades. Eles ocupam espaços menos valorizados, regular ou irregularmente, e impulsionam a urbanização mais precária, sofrendo dia após dia as carências presentes de infra-estrutura e serviços (PIERRI, 2003).

Um indicador eloqüente do primeiro processo é o fluxo de turistas na temporada. As estatísticas da Secretaria de Estado do Turismo (Setu) (2006) informam que este atingiu uma média de 1.518 .826 pessoas nas temporadas do período 2000 a 2006, com um mínimo de 1.365 .885 turistas em 2002, e um máximo de 1.643.892 turistas, em 2005. Esse fluxo se distribui de forma desigual entre os sete municípios e a Ilha do Mel, que, embora pertencente ao município de Paranaguá, discrimina-se por ser um local turístico diferenciado. O município que recebe mais turistas é Pontal do Paraná, com aproximadamente $35 \%$ do total, em 2005. Segue-o Matinhos, com 25\%, e Guaraqueçaba, com $15 \%$. Morretes recebe $8 \%$, Paranaguá, $6 \%$, Ilha do Mel, 4\%, e Guaratuba, 2\% (sETu, 2006) (Quadro 8).
Trata-se de turistas vindos majoritariamente de Curitiba. Entre 1998 e 2005, os turistas dessa origem sempre foram mais da metade do total, com um mínimo de $52,8 \%$ em 2002, e um máximo de 68,8\% em 1999, e em 2005 atingiram $55,8 \%$. A permanência média nesse período oscilou entre 6,7 e 10,3 dias. Salvo em 2002, quando se hospedaram em casa própria $28 \%$, e $30 \%$ em casa de parentes ou amigos; no resto do período considerado, a casa própria é o local de hospedagem majoritário. Em 1998, $47,7 \%$ do total de turistas foram a casa própria, e 32,2\%, em 2005. A segunda opção mais concorrida é a casa de parentes ou amigos, pela qual optaram entre um mínimo de 23,9\% dos turistas, em 1998, e um máximo de 33,6\%, em 2004. A grande maioria viaja junto com a família (entre um mínimo de 59,8\%, em 2002, e um máximo de $80,7 \%$ em 1998), e visita o litoral mais de uma vez (entre um mínimo de $85,9 \%$, em 2001, e o máximo de $93,1 \%$, em 1998). O meio de transporte preferencial é o automóvel, com um mínimo de 51,3\% dos turistas, em 2004, e um máximo de 76,5\%, em 1998. Em 2005, 62,4\% utilizaram esse meio. $\mathrm{O}$ gasto médio diário per capita declarado gira em torno de US\$ 14 no período analisado, com 
QUADRO 8 - PERFIL DO TURISTA QUE VISITA O LITORAL DO PARANÁ - 1998-2005

\begin{tabular}{|c|c|c|c|c|c|c|c|}
\hline \multirow[t]{2}{*}{ Variáveis } & \multicolumn{7}{|c|}{ ANOS } \\
\hline & 1998 & 1999 & 2000 & 2001 & 2002 & 2004 & 2005 \\
\hline \multicolumn{8}{|l|}{ Procedência (\%) } \\
\hline Curitiba & 63,3 & 68,8 & 57,2 & 53,3 & 52,8 & 56,3 & 55,8 \\
\hline Região metropolitana & 7,3 & 6,8 & 7,6 & 7,2 & 7,7 & 9,1 & 9,1 \\
\hline Outros/Paraná & 21,4 & 17,8 & 19,4 & 19,9 & 23,8 & 21,2 & 20,4 \\
\hline Outros BR & 6,9 & 5,2 & 14,2 & 17,5 & 14 & 11,6 & 12,3 \\
\hline Exterior & 1,1 & 1,4 & 1,6 & 2,1 & 1,7 & 1,8 & 2,4 \\
\hline Permanência média (dias) & 10,3 & 6,7 & 7,5 & 6,7 & 8,5 & 8,0 & 7,9 \\
\hline Renda média p/c US\$ & $1.297,7$ & 790,0 & $1.062,0$ & 955,3 & 1017,1 & 570,4 & 793,1 \\
\hline Gasto médio/dia p/c (US\$) & 17,1 & 12,5 & 12,6 & 13,7 & 13,5 & 13,2 & 15,4 \\
\hline \multicolumn{8}{|l|}{ Transporte (\%) } \\
\hline Automóvel & 76,5 & 69,3 & 69,6 & 63,2 & 59,5 & 51,3 & 62,4 \\
\hline Ônibus & 22,0 & 28,2 & 25,8 & 29,5 & 36,6 & 45,9 & 31,8 \\
\hline \multicolumn{8}{|l|}{ Hospedagem } \\
\hline Hotel & 2,5 & 3,3 & 5,6 & 7,1 & 14,5 & 11,0 & 14,3 \\
\hline Aluguel & 18,7 & 21,1 & 19,3 & 17,8 & 17,7 & 14,8 & 15,9 \\
\hline Casa própria & 47,8 & 40,1 & 37,4 & 28,2 & 28,0 & 33,1 & 32,2 \\
\hline Casa parentes/amigos & 23,9 & 25,6 & 27,8 & 25,6 & 30,0 & 33,6 & 33,4 \\
\hline Outros & 7,2 & 9,9 & 9,9 & 21,3 & 10,8 & 7,5 & 4,2 \\
\hline \multicolumn{8}{|l|}{ Modo de viajar } \\
\hline Só & 10,3 & 14,6 & 13,7 & 13,1 & 18,6 & 17,6 & 17,1 \\
\hline Em grupo & 8,8 & 16,3 & 10,0 & 14,5 & 21,2 & 22,3 & 13,8 \\
\hline Com família & 80,7 & 69,0 & 76,1 & \begin{tabular}{|l|}
72,2 \\
\end{tabular} & 59,8 & 60,0 & 68,3 \\
\hline
\end{tabular}

FONTE: Modificado de Setu (2006).

um mínimo de US\$12,5, em 1999, e um máximo de US\$ 17,1, em 1998. Em 2005, esse gasto médio diário foi de US\$15,4 que, na verdade, é maior que os US\$17 de 1998, considerando o valor em reais (SETU, 2006) (Quadro 8).

No conjunto, esses dados mostram que o uso turístico do litoral serve, principalmente, a moradores do estado, e destes, particularmente, àqueles que moram na capital, grande parte dos quais possuem nele casa própria. Isto, somado à pouca distância e a estradas em condições relativamente boas, permite-lhes freqüentá-lo assiduamente.
O uso balneário se caracteriza pela procura das praias e a sua ocupação. No Paraná, inicialmente, os balneários se localizaram nas praias mais abrigadas, onde morros próximos ou bancos de areia diminuíam a energia das ondas. Tal o caso das praias mansas de Caiobá e Matinhos, e as praias de Guaratuba e Pontal do Sul.

Posteriormente, foram sendo ocupadas as praias de maior energia de ondas até formar a ocupação contínua do litoral sul do Paraná. No litoral norte, o processo de ocupação por uso balneário foi retardado pela falta de acesso ter- 
restre e pela dificuldade do acesso marítimo. Neste setor, todas as praias localizam-se em ilhas naturais ou artificiais, como é o caso de Superagüi; uma península que foi isolada do continente pela escavação do canal do Varadouro nos anos 60 do século XX. Posteriormente, o potencial de ocupação foi extremamente reduzido, com a criação do Parque Nacional do Superagüi, que inclui as praias do Superagüi e Ilha das Peças. Foram excluídas do parque as vilas de pescadores, notadamente a Vila das Peças e a da Barra do Superagüi, que vem sofrendo crescente pressão por ocupação turística, pois a partir destas vilas se tem acesso às praias desertas do parque.

O uso balneário no litoral centro-sul paranaense tem se caracterizado pela ocupação junto à linha de costa ou mesmo sobre a praia, pela destruição das dunas e paleodunas frontais, pelo aterro de brejos e pela descaracterização de rios e córregos. Ou seja, pela desconsideração da morfologia e, sobretudo, da dinâmica dos ambientes costeiros.

Junto às praias oceânicas, isto é, sem influência das desembocaduras das baías, os problemas de erosão foram deflagrados pela ocupação sobre a praia, ou muito próxima da linha de costa. Os casos da praia Brava de Caiobá e dos balneários Flamingo e Riviera são exemplares deste tipo de ocupação em que as obras de infra-estrutura avançam sobre a praia. Em Caiobá, os problemas de erosão começaram com a construção da Avenida Atlântica sobre a parte central da praia, nos anos 60 (século XX) (ANGULO; ANDRADE, 1982; ANGULO, 1993) (Figura 13).

Quarenta anos depois, os problemas continuam. É conhecido que o processo de erosão costeira tem retro-alimentação positiva, isto é, uma vez iniciado tende a crescer e é de difícil reversão. Por este motivo, uma das melhores medidas, em relação à erosão costeira, é a prevenção. Quando os problemas se iniciam, dependendo do nível de ocupação da orla, a remoção das construções pode ser uma das melhores medidas para resolvê-los. Esta medida tem sido largamente utilizada na Espanha e nos Estados Unidos e continua como uma tendência para resolver problemas de erosão costeira. No Paraná, foi realizada remoção em uma ocupação irregular na praia central de Matinhos, após a "ressaca" de maio de 2000, que destruiu várias residências. Após seis anos houve recomposição da praia e da duna frontal (Figuras 14A e 14B). Em contraste, ao lado, em direção norte, a Avenida Beira-Mar, construída no final dos anos 1980, que iniciou o problema erosivo nos balneários Flamingo e Riviera, continua a agravar o problema no local e a provocar uma onda erosiva para o norte, em direção da deriva litorânea predominante (Figura 15).

Quando a ocupação ocorre muito próxima da linha de costa, embora não avance sobre a praia, pode causar os mesmos problemas, pois a linha de costa é uma feição que se pode mover em direção ao continente durante períodos

FIGURA 13 - FOTO AÉREA VERTICAL DE CAIOBÁ EM 1953. NOTAR QUE O TRAÇADO DAAVENIDA ATLÂNTICA (LINHA VERMELHA) INTERSECTA A LINHA DE COSTA (LINHA AZUL), EVIDENCIANDO QUE PARTE DA AVENIDA FOI CONSTRUÍDA SOBREAPRAIA

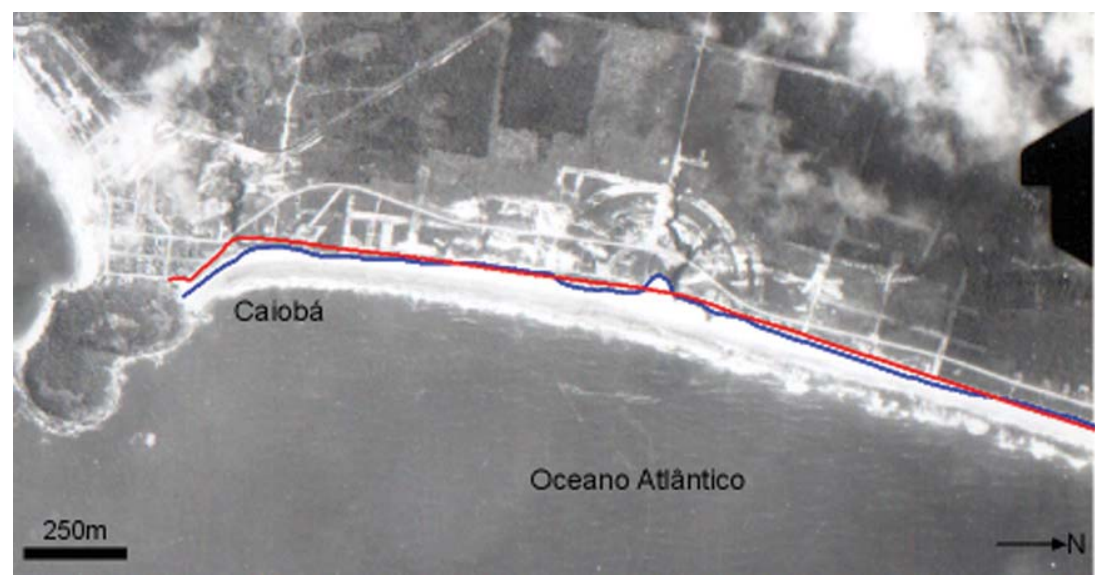


FIGURA 14A - RESIDÊNCIAS DESTRUÍDAS PELA RESSACA DE MAIO DE 2000 EM MATINHOS

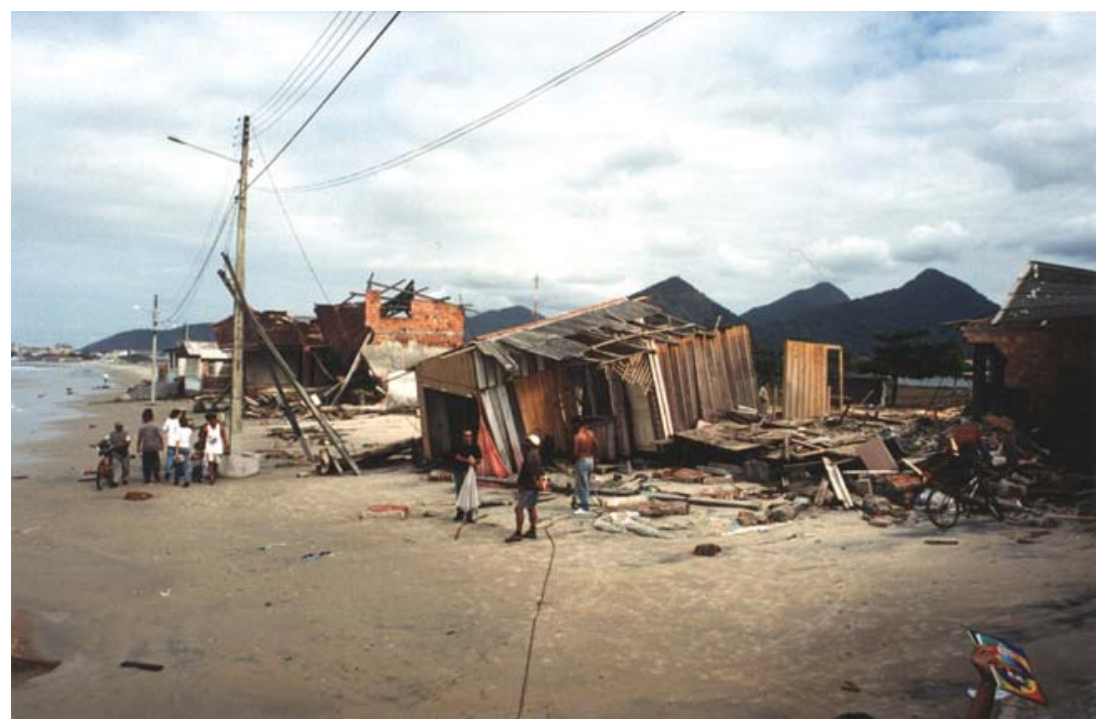

FIGURA 14B - RECOMPOSIÇÃO DO PERFIL PRAIAL E DAS DUNAS FRONTAIS EM 2004 EM MATINHOS

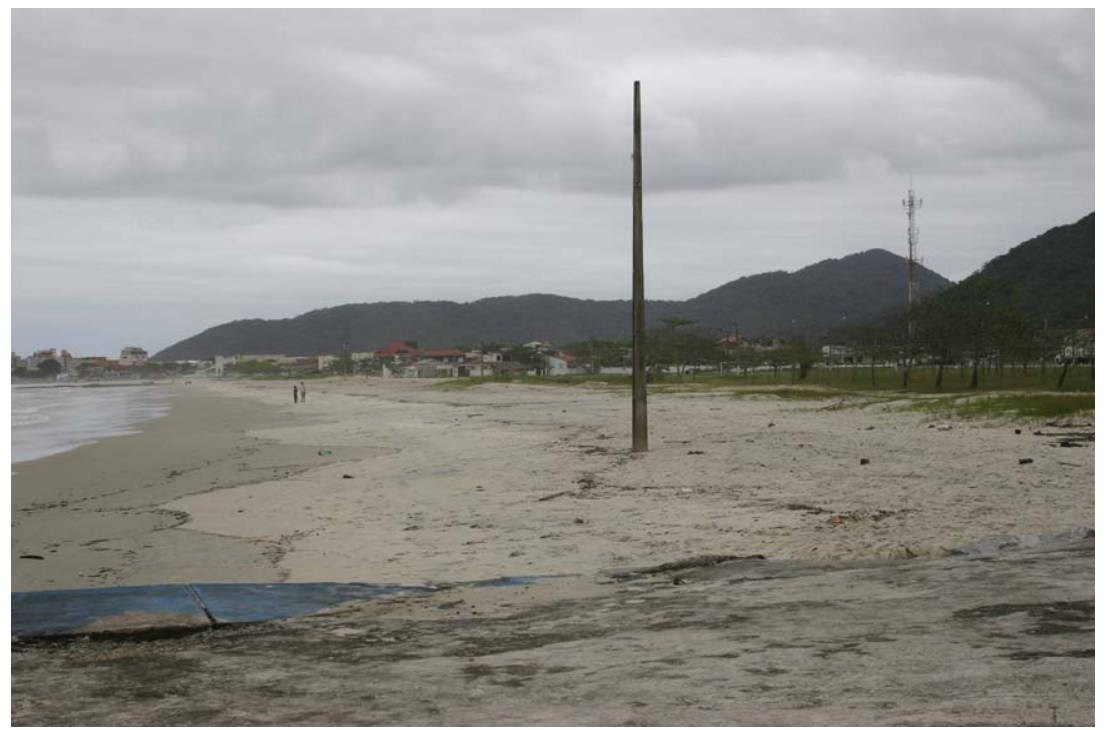




\section{FIGURA 15 - ÁREA COM PROBLEMAS DE EROSÃO DECORRENTES DE OCUPAÇÃO INA- DEQUADA NO BALNEÁRIO FLAMINGO}

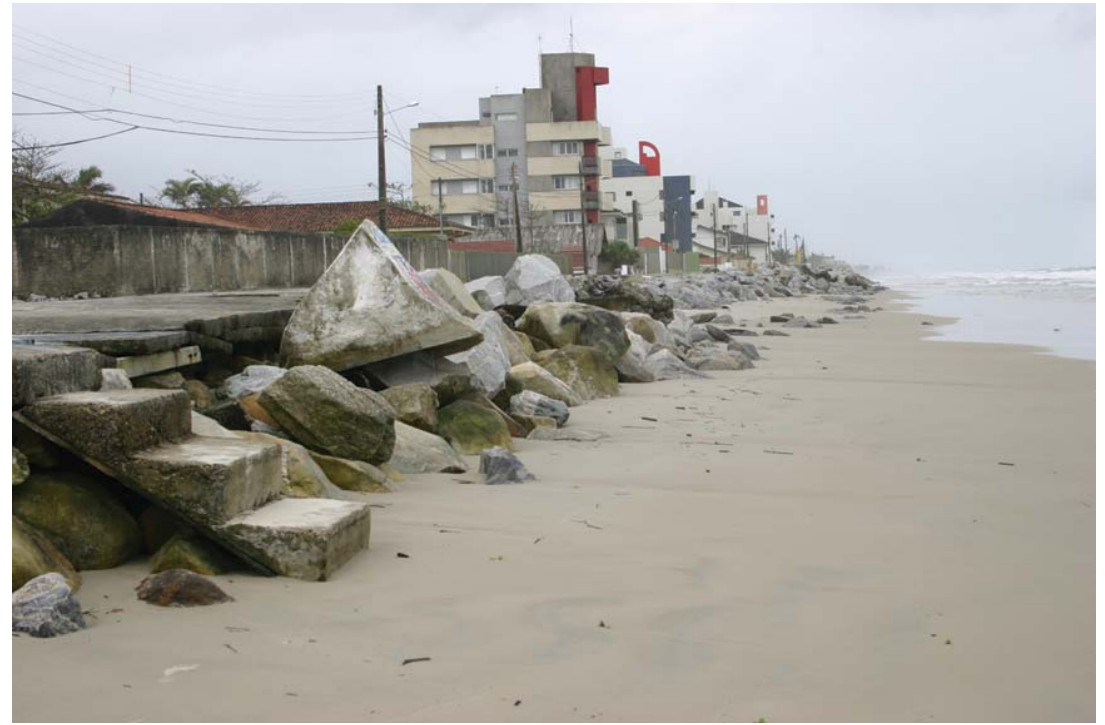

de ondas mais energéticas, e em direção ao mar, em períodos de ondas mais fracas. Este movimento da linha de costa vem acompanhado de mudanças do volume de areia da praia e das dunas frontais. Durante os períodos de ondas fracas ou de bom tempo, a areia tende a se acumular na parte emersa da praia e nas dunas frontais, e durante os períodos de ondas mais fortes ou durante tempestades, grandes volumes de areia podem ser retirados das dunas e da parte emersa da praia e depositados em barras submersas longitudinais à praia. A ocupação muito próxima da linha de costa e a remoção das dunas frontais impedem este ciclo de erosão-reconstrução e desencadeiam processos erosivos irreversíveis.

As praias próximas às desembocaduras, como foi comentado, apresentam alta mobilidade. A ocupação destas áreas requer, portanto, cuidados especiais, sendo recomendado deixar extensas faixas livres. Ao contrário, o que tem sido verificado no Paraná é a ocupação das áreas recentemente emersas, sem considerar que elas podem ser rapidamente destruídas. Na Prainha, próxima à desembocadura da Baía de Guaratuba, um loteamento de uma quadra de profundidade foi implantado em terrenos que não existiam nos anos 1950 (ANGULo, 1984) (Figura 16). Em Pontal do Sul, o loteamento Jardim Marines também foi implantado em ter- ras emersas após os anos 1950. Depois de 2000, problemas relacionados à mobilidade das costas de desembocadura ocorrem nas barra do Superagüi e do Ararapira.

Um caso particular de ocupação no litoral paranaense é o da Ilha do Mel, que constitui hoje seu maior atrativo turístico. Com antecedentes de ocupação por motivos militares nos séculos XVIII e XIX, na década de 30 do século $\mathrm{XX}$ teve a primeira onda de uso turístico por parte de famílias de classe alta de Curitiba, que compraram terrenos e construíram casas, mas sem proporções importantes. Compartilhavam o espaço com a população tradicional permanente de pescadores, sem maiores conflitos. Na Segunda Guerra Mundial (1939-1945) a ilha voltou a ser considerada "zona de guerra", o que operou como restrição aos outros usos. Passado esse período excepcional, a ilha continuou sendo compartilhada por pescadores tradicionais e poucos turistas, favorecida pelo isolamento e a falta de estrutura (ATHAYDE; BRITEZ, 2005).

Mas a partir da década de 1980 a pressão turística começou a crescer. Simultaneamente, a maior parte da ilha foi transformada em área de conservação sob regime bem restrito. Em 1982, foi criada uma Estação Ecológica de 2.240 ha. Isso não impediu o avanço turístico, muito pelo contrário, o legitimou, autorizando seu desenvolvimento nas áreas 


\section{FIGURA 16 - PRAIA DA PRAINHA EM 1954 (A) E EM 1980 (B). NOTAR OCUPAÇÃO SOBRE ÁREAACRES- CIDA ENTRE 1954 E 1980 (ANGULO, 1984)}
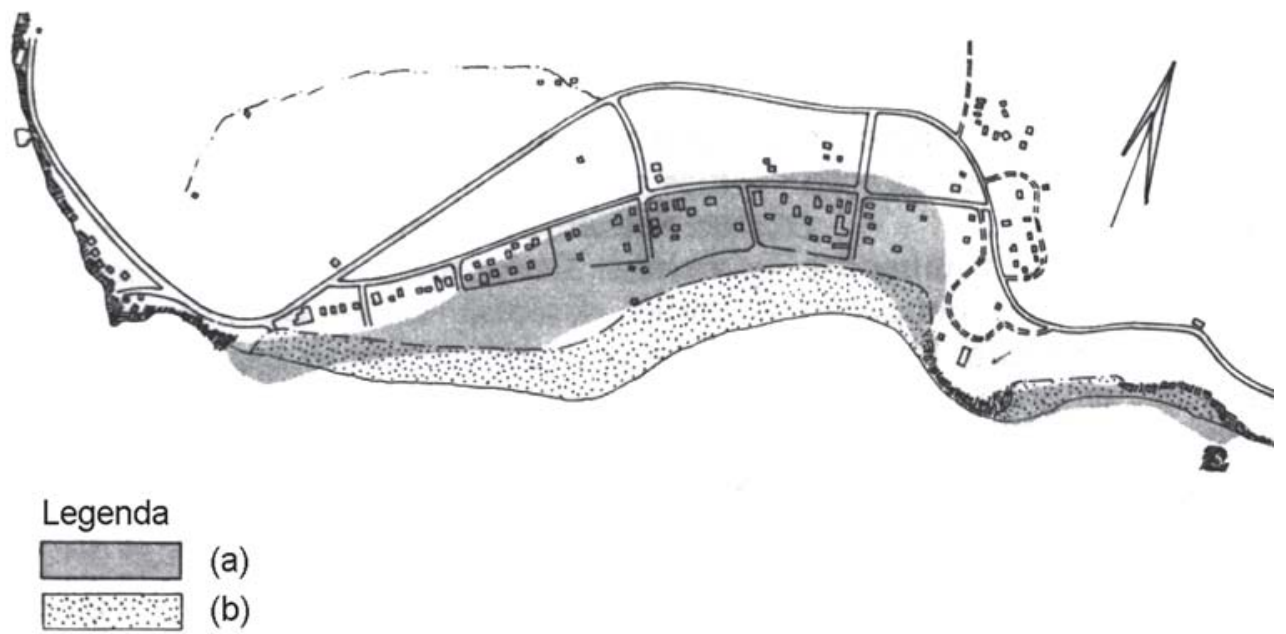

externas à Estação, que são áreas de amortecimento com regulação ambiental específica. Foi assim que a instalação de luz elétrica, em 1988, e o serviço regular de transporte marítimo desataram um movimento de ocupação mais intenso, de investidores turísticos, de veranistas que compraram casa, e de visitantes de um ou vários dias. Operam, entre outras medidas reguladoras, restrições aos direitos de posse de terra, e ao tipo e materiais das construções, assim como um limite de 5000 pessoas que podem estar simultaneamente na ilha, definido como sua "capacidade de suporte". Em 2002, foi criado um Parque Estadual com superfície de 338 ha, que, somados à Estação Ecológica, totalizam 2.578 ha, ficando $93,4 \%$ da superfície total da ilha sob regime de conservação restrita (ATHAYDE; BRITEZ, 2005). Por estar na desembocadura da baía de Paranaguá, a ilha tem costas de alta mobilidade, e sofreu diversos problemas erosivos desde o início de sua ocupação (FIGUEIREDO, 1954).

Quanto ao uso turístico voltado para a navegação de recreação, este se caracteriza, principalmente, pela necessidade de marinas e portos, que demandam áreas de apoio em terra e acesso às baías. No Paraná as marinas se localizam dentro das baías de Paranaguá e Guaratuba, em áreas abrigadas. Todas as cidades costeiras paranaenses têm marinas. Algumas se localizam em áreas naturais abrigadas dos ventos e das ondas e apresentam calados propícios, tais como a da ilha da Cotinga. Outras demandam aterros e dragagens, tal como a do iate clube de Caiobá e a marina Porto do Sol, que foram implantadas em áreas de mangues ou planícies úmidas de altitude próxima ao nível do mar (Figuras 17 e 18).

Em Pontal do Sul, as marinas vêm sendo implantadas ao longo das margens dos canais escavados pelo DNOS, na década de 1960 (Figura 19). Nos últimos anos houve um acentuado aumento da demanda por este tipo de equipamento. Por exemplo, em Ponta do Paraná, foram construídas 18 marinas no Canal do DNOS, e uma na Ponta do Poço, que abrigam, aproximadamente, 1500 embarcações (SPREA, ${ }^{6}$ comunicação pessoal).

Contudo, os locais para implantação de marinas são relativamente escassos na costa paranaense, pois a maior parte das costas estuarinas tem planícies costeiras com manguezais, que, por serem protegidos por lei, se constituem numa barreira para sua implantação. Desse modo, a pressão de ocupação por esse tipo de instalação deve-se concentrar nas costas estuarinas sem mangue, que coincidem com as áreas de ocupação das populações tradicionais de pescadores, gerando conflitos latentes ou manifestos.

\footnotetext{
6 Sr. Edilson Darlei Sprea, atual presidente da Associação de Usuários do Canal de DNOS (marinas), em entrevista realizada pela Dra. Man Yu Chang, em 11 de fevereiro de 2007, Pontal do Sul.
} 

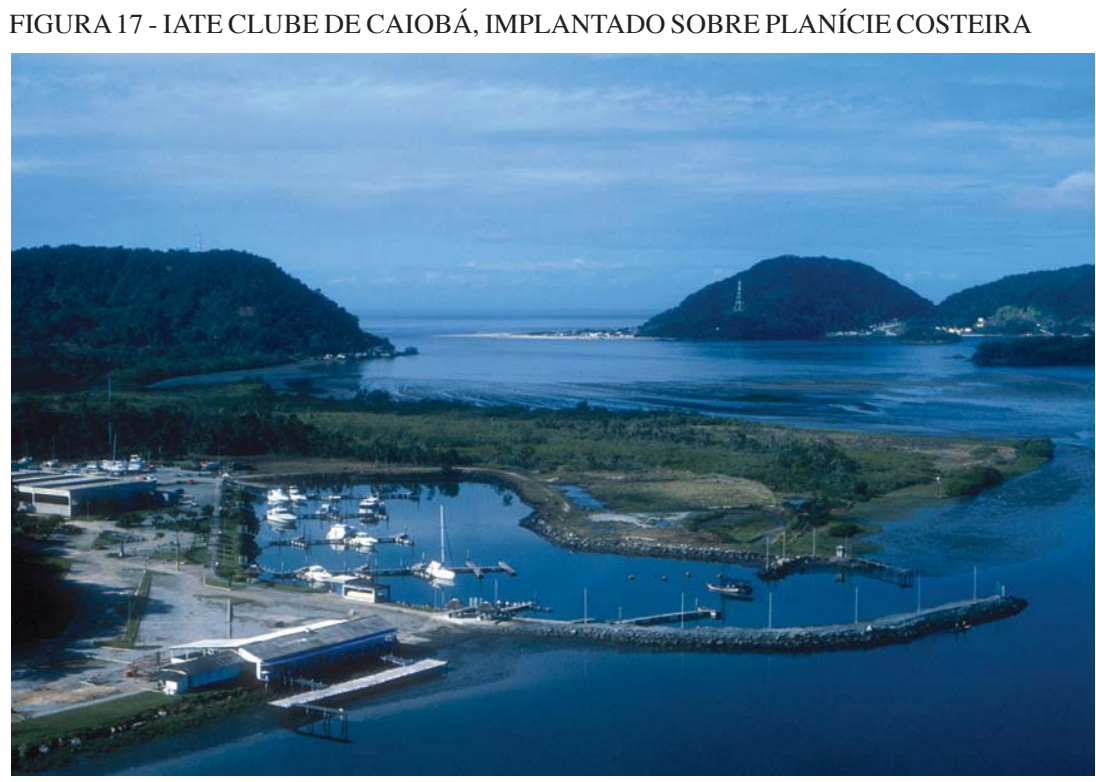

FIGURA 18 - MANGUEZAIS EXISTENTES EM 1954 EM PIÇARRAS, BAÍA DE GUARATUBA (EM VERDE), QUE FORAM ATERRADOS OU ESCAVADOS PARAAIMPLANTAÇÃO DE MARINAS. (MORROS EM VERMELHO E PRAIA EM AMARELO)

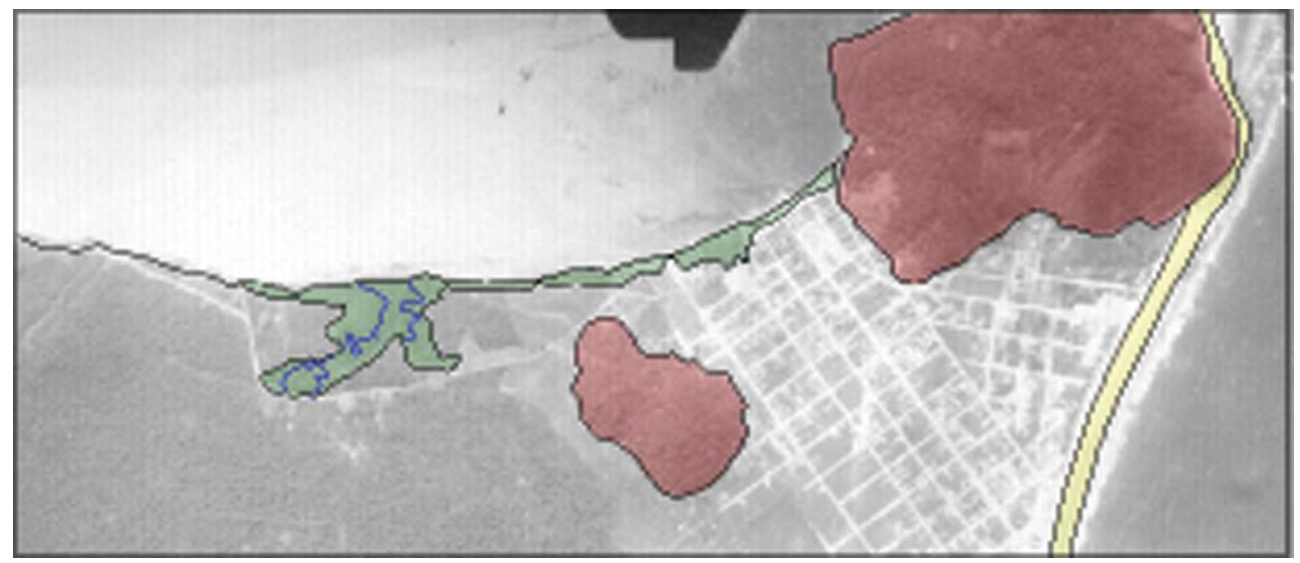

O reflexo do processo de ocupação e de uso do litoral na dinâmica demográfica recente

Nos últimos 30 anos, a população do litoral paranaense duplicou, passando de 112.310 habitantes, em 1970, a 235.840, em 2000, a uma taxa média de crescimento anual de $2,25 \%$. Este crescimento é maior que o do estado, de for- ma que nesses 30 anos a população do litoral passou de representar $1,6 \%$ da população paranaense a representar $2,5 \%$. Trata-se de um crescimento predominantemente urbano, de forma que a taxa de urbanização do litoral, como um todo, passou de 69\%, em 1970, a 89\%, em 2000, enquanto a estadual foi, nesta última data, de aproximadamente $81 \%$, similar à do Brasil. Isso foi acompanhado de um decréscimo absoluto da população rural (IBGE, 2001; PIERRI, 2003) (Quadro 9). 
FIGURA 19 - MARINAS NO CANAL RETIFICADO DO RIO PEREQUÊ EM PONTAL DO SUL

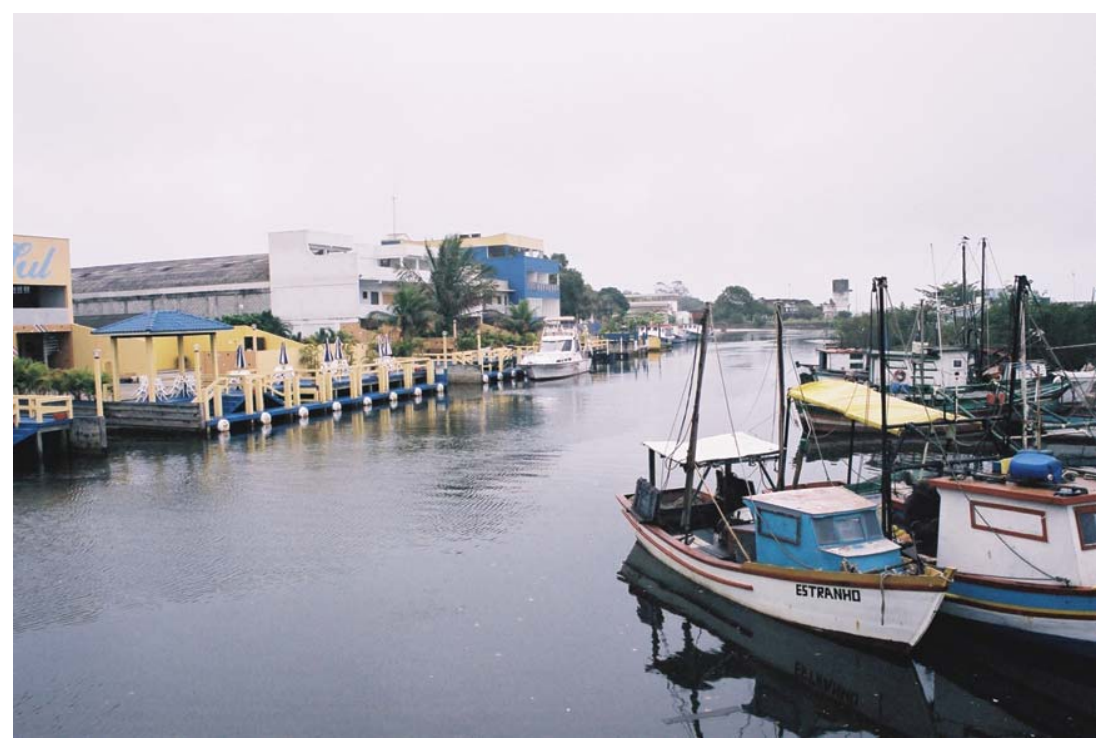

QUADRO 9 - POPULAÇÃO E TAXAS DE CRESCIMENTO ANUAL POR SITUAÇÃO DE DOMICÍLIO. TAXAS DE URBANIZAÇÃO - MUNICÍPIOS DO LITORAL PARANAENSE - 1970 A 2000

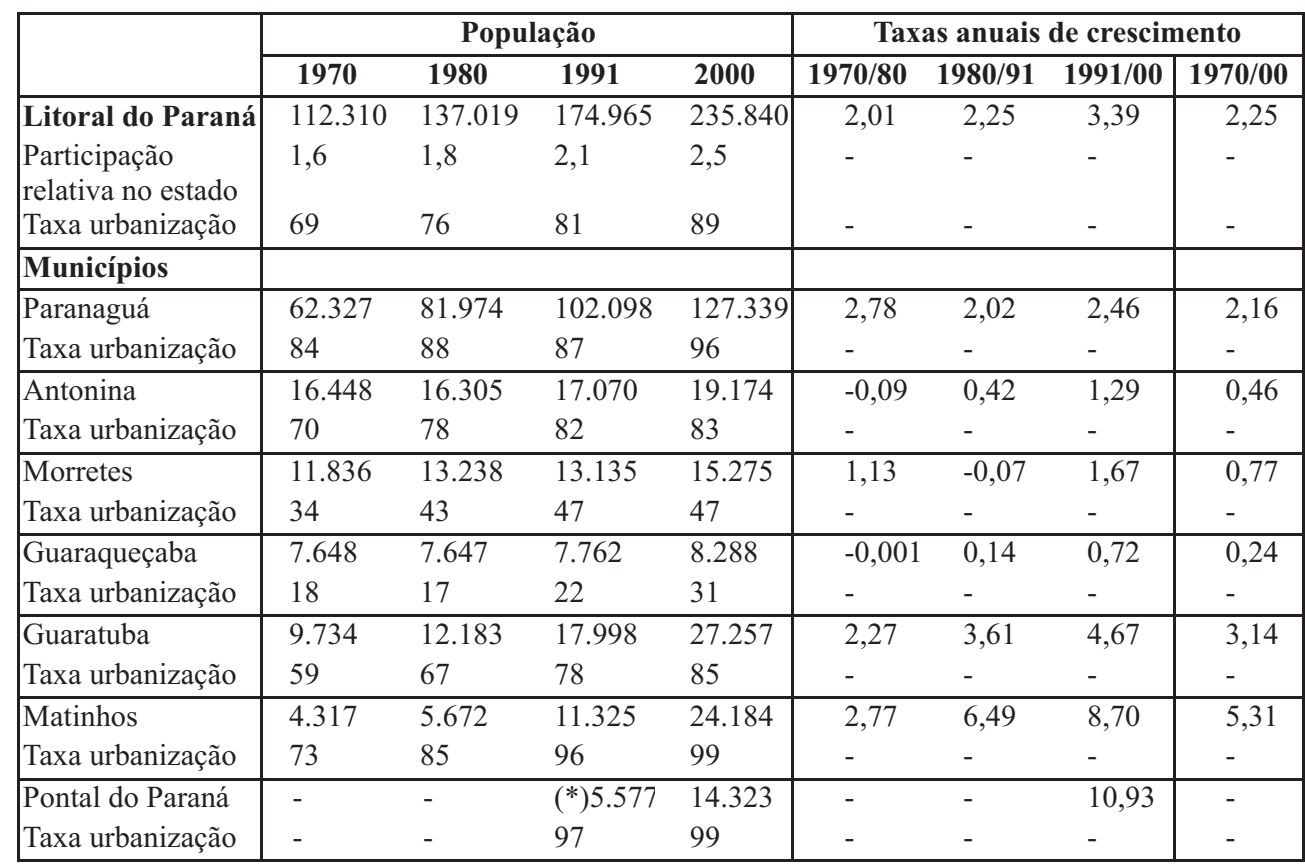

FONTE: IBGE - Censos Demográficos 1970 - 2000. Modificado de Pierri, 2003.

(*) Reconstituída em base a dados de setores censitários do Censo 1991. 
Em conjunto, isso expressa dois processos simultâneos, e parcialmente relacionados. Por um lado, a urbanização responde à migração campo-cidade acontecida, dentro do litoral, como consequiência dos processos de perda de competitividade das atividades agrícolas tradicionais, incentivos à atividade florestal e desenvolvimento da bovinocultura, com a concomitante concentração da propriedade da terra, reforçados pelas limitações ambientais nas áreas de conservação. Isto complementado com as expectativas que os centros urbanos criam de oferecer melhores oportunidades de geração de renda. Por outro, o crescimento populacional veloz, e muito acima do vegetativo, sinaliza a imigração de população originária de outras regiões extralitorâneas como fator explicativo principal, que vem a reforçar a urbanização porque ocupa áreas urbanas (PIERRI, 2003).

Observando-se os desempenhos municipais em termos de crescimento e urbanização, aparecem situações diferentes que refletem, nem que não seja linearmente, os processos regionais descritos. Por um lado, Paranaguá se destaca claramente por ter duplicado sua população entre 1970 e 2000, por concentrar ao longo de todo o período a metade da população litorânea, e por atingir altas taxas de urbanização (96\%, em 2000) (IBGE, 2001). Em conjunto, esses indicadores expressam sua condição de pólo econômico regional. Do outro lado, Antonina aparece com uma população total bem menor (19.174, em 2000) e com taxas de crescimento baixas e até negativas no período, que estariam refletindo, em grande parte, a crise derivada da perda de seu protagonismo portuário e a atividade industrial que o acompanhava, induzindo à emigração e desestimulando a imigração.

Guaraqueçaba é o município com menor população absoluta (8.288 habitantes, em 2000) e o que menos cresceu ( $0,24 \%$ ao ano) nos 30 anos considerados. Também é o que apresenta o menor grau de urbanização: $31 \%$ (IBGE, 2001). Isso reflete seu isolamento maior relativo, as sucessivas crises econômicas, e as severas restrições ambientais por ter-se constituído em área de conservação, tudo isso se combina, reforçando sua marginalização econômica, que acaba induzindo à emigração e o descarta do horizonte dos possíveis imigrantes.

Por outro lado, o município de Morretes também apresenta baixa população (15.275 habitantes, em 2000), predominantemente rural (53\%), e baixa taxa de crescimento (0,77\% ao ano) no período 1970-2000 (IBGE, 2001). Provavelmente esses indicadores expressam também a crise agrí- cola do litoral e o fato de que o turismo de tipo históricocultural que ali se desenvolve não consegue um desempenho equivalente ao do turismo de "sol e praia" dos municípios costeiros do litoral sul.

Já Guaratuba, Matinhos e Pontal do Sul aparecem como um grupo diferenciado, apresentando altíssimas taxas de crescimento populacional e de urbanização. Entre 1970 e 2000, Guaratuba, grosso modo, triplicou sua população (de 9.734 passou a 27.257 habitantes), e Matinhos a sextuplicou (de 4.317 a 24.184). Pontal do Paraná, em apenas 9 anos, entre 1991 e 2000, multiplicou sua população duas vezes e meia: de 5.577 passou a ter 14.323 habitantes, apresentando a maior taxa de crescimento anual médio de todo o litoral: 10,93\%. Em termos de urbanização, nos 30 anos considerados, Guaratuba passou de uma taxa de urbanização de 59\% a $85 \%$; Matinhos, de $73 \%$ a $99 \%$. Pontal do Paraná, de 97\% em 1991, a 99\% em 2000 (IBGE, 2001). Estes indicadores refletem, fortemente, o "boom" gerado pela ocupação balneária ligada ao turismo de "sol e praia", que convocou um processo acelerado de investimentos, construção imobiliária e instalação de comércio e serviços. Esse fenômeno constitui os municípios de uso balneário numa "zona de fronteira" do estado, que vem sendo ocupada por um massivo fluxo de imigrantes provenientes, principalmente, de outras regiões do Paraná, e, secundariamente, de estados vizinhos (PIERRI, 2003).

Esse "boom", nem que espetacular em escala local, não chega a questionar o caráter de pólo regional, econômico, comercial e administrativo de Paranaguá. Mas indica que os municípios praiano-turísticos se constituíram, claramente, no segundo pólo de desenvolvimento do litoral. Isso não quer dizer que este novo pólo tenha atingido um alto e permanente dinamismo econômico, nem que reverta em distribuição significativa de riqueza. Nesse sentido, dados analisados por Pierri (2003) sinalizam que grande parte da população permanente dos municípios balneários se encontra em situação de pobreza relativa, com níveis de escolaridade e de renda baixos, e que ocupa espaços ambientalmente inadequados. E isso acontece também em Paranaguá, onde o grande volume de riqueza que passa pelo porto não reverte significativamente para elevar a qualidade de vida da população local.

Por último, a anunciada instalação de terminais portuários em Pontal do Paraná criará uma confluência local inédita da atividade portuária e a turística, cuja compatibilidade será um grande desafio. Mas, independentemente de como isso transite, pode-se afirmar que esse elemento 
iniciará, sem dúvida, uma nova fase na configuração espacial e econômica do litoral.

\section{Considerações finais}

O processo histórico acontecido desde a colônia até o presente no litoral do estado do Paraná atribuiu a esta região significados e papéis distintos por meio dos espaços ocupados e os seus usos.

Respondendo à via marítima que tinha a colonização no século XVI, o litoral paranaense, e em particular a Baía de Paranaguá foi uma das portas abertas pelos colonizadores às riquezas que pretendiam explorar nas novas terras, que, primeiro, e principalmente, eram os metais preciosos. Daí o primeiro cenário, com um porto protegido na baía, e a exploração do ouro.

A fase agrícola seguinte explorou o solo naqueles produtos que eram os mais atrativos comercialmente, seguindo, até certo ponto, os ciclos econômicos do país. $\mathrm{O}$ grande limite foi a perda de competitividade, sob a conjunção da baixa qualidade do solo e a preferência do capital por investir em outras regiões. O fim dessa fase trasladou, definitivamente, o centro de desenvolvimento do litoral para ao planalto, de Guaraqueçaba para outras regiões onde se desenvolveu a economia agrícola de grande escala e, depois, a indústria moderna.

$\mathrm{Na}$ fase seguinte, e por muito tempo, o papel do litoral ficou praticamente reduzido a sua função portuária, servindo para escoar os produtos criados nas regiões privilegiadas pelo capital para o exterior. Antonina primeiro, e depois principalmente Paranaguá, até o presente, desempenharam esse papel, caracterizando o uso costeiro portuário analisado.

Paralelamente, e como outro desdobramento da crise agrícola, constitui-se o uso pesqueiro, em primeiro termo, como uma estratégia de sobrevivência da população nativa, e mais recentemente, com caráter comercial, chegando, principalmente no litoral sul, a formas mais capitalizadas, sob a influência açoriana importada de Santa Catarina. Mas este uso sempre foi secundário em relação ao portuário, e nunca teve relevância para o desenvolvimento econômico do estado.

Só nas últimas décadas do século XX o litoral se constitui, também, num espaço de investimento turístico, oferecendo oportunidades de descanso e lazer, majoritariamente a curitibanos de classe média e, em menor grau, a pessoas do interior do estado, da mesma condição social. Esse perfil turístico configurou o uso balneário dos municípios praianos, e está ainda em construção.

Finalmente, a grande extensão de natureza preservada do litoral paranaense, de valor ambiental mais que econômico, propiciou, no contexto político contemporâneo de preocupação pela proteção da natureza e da biodiversidade, que se tenha constituído a maior parte de seu território em área de conservação, caracterizando o quarto uso analisado.

Assim, no presente, o litoral deste estado se pode definir como uma grande área de conservação (82\% de seu território) com um grande porto de exportação. Ambos os usos de seu solo não atendem primeiro, nem principalmente, à população litorânea: o primeiro, teoricamente, atende às gerações presentes e futuras; o segundo, ao comércio internacional, à economia do país e do estado e, em particular, aos setores produtivos exportadores.

Secundariamente, o litoral destina parte de seu solo para o uso balneário e o uso pesqueiro. $\mathrm{O}$ primeiro, para desfrute principal dos cidadãos curitibanos e de outras regiões que escolhem esse lugar para descansar em certas épocas do ano; e o segundo, o uso pesqueiro, é o único cujos beneficiários principais são pessoas que vivem no litoral o ano todo.

Como resultado do anterior, pode-se dizer que os principais usos historicamente determinados do solo do litoral do Paraná alienam a sua população de seus principais benefícios, formulando novamente o paradoxo do contraste entre riqueza natural e pobreza social, mas também o contraste entre tanta riqueza social de outros, externos à região, e a pobreza dos locais. 


\section{Referências}

ANDRIGUETTO FILHO J. M. Sistemas técnicos de pesca e suas dinâmicas de transformação no litoral do Paraná, Brasil. Curitiba, 1999. 242 p. Tese (Doutorado em Meio Ambiente e Desenvolvimento) - Universidade Federal do Paraná.

; MARCHIORO, N. P. X. Diagnóstico e problemática para a pesquisa. In: REYNAUT, C. et al. (Eds.). Desenvolvimento \& meio ambiente. Em busca da interdisciplinaridade. Pesquisas urbanas e rurais. Curitiba: UFPR, 2002. p. 159-194.

- A mudança técnica e o processo de diferenciação dos sistemas de produção pesqueira do Litoral do Paraná, Brasil. Desenvolvimento e Meio Ambiente, Dinâmicas Naturais dos Ambientes Costeiros: Usos e Conflitos, n. 8, p. 43-58, 2003.

et al. Diagnóstico da pesca no estado do Paraná. Publicação Especial do Programa Instituo do Milênio. Projeto Recos. (MCT/CNPq-PADCT), Modelo Gerencial da Pesca. Revista Atlântica, Rio Grande, 2005.

ANGULO, R. J. As praias do Paraná: problemas decorrentes de uma ocupação inadequada. Análise Conjuntural, v. 1, n. 6 , p. 1-4, 1984.

A ocupação urbana do litoral paranaense e as variações da linha de costa. Boletim Paranaense de Geociências, v. 41, p. 73-81, 1993.

; ANDRADE J. J. Viabilidade de controle de erosão nas praias de Caiobá e Guaratuba. In: SIMPÓSIO BRASILEIRO DE SENSORIAMENTO REMOTO, 2., 1982, Brasília. Anais... Brasília: INPE, v. 3, 1982. p. 681-693.

; SOUZA M. C. DE; LAMOUR M. R. Coastal erosion problems induced by dredging activities in the navigation channel of Paranaguá and São Francisco do Sul harbor, Southern Brazil. Journal of Coastal Research, SI-39, p. 1-6, 2006.

ANTAQ - Agência Nacional de Transportes Aquaviários. Desempenho Portuário e Séries Históricas. Disponível em: $<$ http://www.antaq.gov.br/IndexPortos.asp>. Acesso em: 26 jun. 2006.

APPA - Administração dos Portos de Paranaguá e Antonina. Histórico dos portos de Antonina e Paranaguá. Disponível em: <http://www.portosdoparana.com.br>. Acesso em: 5 jul. 2006.

ATHAYDE, S. F. DE; BRITEZ, R. M. DE. As unidades de conservação. In: MARQUES, M. C.; BRITEZ, R. M. DE
(Orgs.). História natural e conservação da Ilha do Mel. Curitiba: UFPR, 2005. p. 229-248.

BIGARELLA, J. J. Matinho: Homem e Terra - Reminiscências. 2. ed. Matinhos, PR: Prefeitura Municipal de Matinhos; Fundação João José Bigarella para Estudos e Conservação da Natureza, 1999. 212 p.

DESCHAMPS, M. Dinâmica demográfica do litoral do Paraná. Diagnóstico do Estudo de Avaliação de Impacto Ambiental do Porto de Ponta do Poço, Meio Socioeconômico, em prep.

FIGUEIREDO, J. C. Contribuição à geografia da Ilha do Mel (Litoral do Estado do Paraná). Curitiba, 1954. 61 p. Tese (Cátedra Geografia do Brasil) - Faculdade de Filosofia, Universidade do Paraná.

GIANNINI, P. C. F. et al. A erosão na costa leste da Ilha do Mel, baía de Paranaguá, Estado do Paraná: Modelo baseado na distribuição espacial de formas deposicionais e propriedades sedimentológicas. Revista Brasileira de Geociências, v. 2, n. 34, p. 231-342, 2004.

IAP - Instituto Ambiental do Paraná, 2006. Memória de Cálculo e Extrato Financeiro do ICMS Ecológico por Biodiversidade, em Reais, Acumulado por Mês e Individualizado por Município e por Unidade de Conservação ou Área Protegida. Disponível em: <http://www.pr.gov.br/ meioambiente/iap/biodiver.shtml>. Acesso em: 02 jul. 2006.

IBGE-Instituto Brasileiro de Geografia e Estatística. Censo demográfico 2000. Características da população e dos domicílios. Resultados do universo. Rio de Janeiro: IBGE, 2001.

Censo demográfico 2000. Agregado de setores censitários dos resultados do universo. Rio de Janeiro: IBGE, 2002.

IPARDES - Instituto Paranaense de Desenvolvimento Econômico e Social. Zoneamento da APA de Guaraqueçaba. Curitiba: Ipardes, 2001.

KIM, M. K. Análise da sustentabilidade do atual modelo de desenvolvimento da Ilha do Mel. Pontal do Sul, 2004. Monografia (Curso de Graduação em Oceanografia) - Universidade Federal do Paraná.

LIMA, E. R. et al. Caracterização do Nimad e do litoral paranaense. In: LIMA, R. E.de; NEGRELLE, R. B. (Orgs.). Meio ambiente e desenvolvimento no litoral do Paraná: Diagnóstico. Curitiba: UFPR, 1998. p. 3-12. 
MARTIN, L. et al. Mapa geológico do Quaternário costeiro dos estados do Paraná e Santa Catarina. Brasília: DNPM, 28/18, 1988. 40 p. (Série Geologia)

MT-MINISTÉRIO DOS TRANSPORTES. Anuário estatístico e site dos principais portos marítimos. Disponível em: $<$ http://www.transportes.gov.br>. Acesso em: 26 jun. 2006.

PARELLADA, C. I.; GOTTARDI NETO, A. Inventário de sambaquis do litoral do Paraná. Boletim Paranaense de Geociências, Curitiba, n. 42, p.121-152, 1994.

PIERRI, N. O litoral do Paraná: entre a riqueza natural e a pobreza social Desenvolvimento e Meio Ambiente, Curitiba, n. 8, p. 25-41, jul./dez. 2003.

RAYNAUT, C.; ZANONI, M.; LANA, P. O desenvolvimento sustentável regional: o que proteger? Quem desenvolver? In: RAYNAUT, C. et al (Eds.). Desenvolvimento \& meio ambi- ente. Em busca da interdisciplinaridade. Pesquisas urbanas e rurais. Curitiba: UFPR, 2002. p. 235-248.

RODRIGUES, A. et al. É correto pensar a sustentabilidade a nível local? Uma análise metodológica de um estudo de caso em uma área de proteção ambiental no litoral sul do Brasil. Ambiente e Sociedade, Campinas, v. 5, n. 2, p. 109-127, ago./ dez. 2002; v. 6, n. 1, jan./jul. 2003.

SAMPAIO, R. Uso balneário, apropriação do espaço e meio ambiente em Pontal do Paraná, litoral paranaense. Curitiba, 2006. Tese (Doutorado em Meio Ambiente e Desenvolvimento) - Universidade Federal do Paraná.

SETU-Secretaria de Estado do Turismo. Estudo de demanda turística do Litoral, 2006. Demanda-Litoral. Estatísticas do Turismo. Disponível em: <http://www.pr.gov.br/turismo/ estatisticas.shtml>. Acesso em: 25 ago. 2006. 